\title{
Application of Red Mud in Wastewater Treatment
}

\author{
Li Wang 1,2,3, Guangyan Hu ${ }^{1,2}$, Fei Lyu ${ }^{1,2}$, Tong Yue ${ }^{1,2}$, Honghu Tang ${ }^{1,2, *}$, Haisheng Han ${ }^{1,2}$, \\ Yue Yang ${ }^{1,2}$, Runqing Liu ${ }^{1,2}$ and Wei Sun $1,2, *$ \\ 1 School of Minerals Processing and Bioengineering, Central South University, Changsha 410083, China; \\ Li-wang@csu.edu.cn (L.W.); hugy0624@csu.edu.cn (G.H.); lvfei2012@csu.edu.cn (F.L.); \\ yuetong@csu.edu.cn (T.Y.); hanhaishengjingji@126.com (H.H.); Eric1911@126.com (Y.Y.); \\ liurunqing@126.com (R.L.) \\ 2 Key Laboratory of Hunan Province for Clean and Efficient Utilization of Strategic Calcium-Containing, \\ Mineral Resources, Central South University, Changsha 410083, China \\ 3 State Key Laboratory of Mineral Processing (Beijing), General Research Institute of Mining \& Metallurgy, \\ Beijing 100160, China \\ * Correspondence: honghu.tang@csu.edu.cn (H.T.); sunmenghu@csu.edu.cn (W.S.); \\ Tel.: +86-731-88879622 (H.T.); +86-731-88830482 (W.S.); Fax: +86-731-88710804 (H.T.); +86-731-88660477 (W.S.)
}

Received: 13 March 2019; Accepted: 1 May 2019; Published: 7 May 2019

Abstract: Red mud (RM) is an industrial waste produced in large amounts during alumina extraction from bauxite. Its disposal generates serious environmental pollution due to high alkalinity. Therefore, a strategy for the effective utilization of RM must be developed. For instance, RM may be transformed into useful products, such as adsorbents. Given its high concentrations of aluminum oxides, iron oxides, titanium oxides, silica oxides, and hydroxides, RM may be developed as a cheap adsorbent for the removal of various ions from aqueous solution and soils (e.g., metal and non-metal ions, phenolic compounds, and dyes) and waste gas purification (sulfide and carbide). This review summarizes the background, properties, and applications of RM as an adsorbent. Proper approaches of removing metal and non-metal elements from wastewater are also systematically reviewed and compared. Emphasis is placed on the surface modification of RM to obtain high adsorption. Finally, the scope for future research in this area for RM is discussed in depth.

Keywords: red mud; environmental remediation; polluted water; waste gas; soil

\section{Introduction}

Red mud (RM) is the substantial solid industrial waste produced in alumina production secondary to alkalization and bauxite digestion [1,2]. Approximately 2-3 tons of bauxite is needed to produce 1 ton of alumina. Thus, the amount of RM yield can be estimated by applying the ratio of 1.5 to alumina production data [3]. The global stock of RM was predicted to reach approximately 4 billion tons in 2019, with a production rate of 0.15 billion tons per year [4]. The amount of RM discharged is 0.06 billion tons per year in China, and the stock of RM is over 0.6 billion tons [5]. The annual alumina production data (Figure 1) show that RM production has considerably increased from 2007 to 2018 [6]. In 2018, RM production is approximately 116 million tons worldwide [7]. The grade of bauxite ore continues to decline because of the preliminary exploitation of high-quality bauxite reserves, causing the output of RM to increase. In addition, alumina production has considerably increased worldwide (Figure 1) [8]. China, Oceania, and South America accounted for 54.37\%, 15.49\%, and 8.27\% of the global production of alumina in 2017, respectively, with the rest of the world accounting for approximately $20 \%$ (Figure 1) [8]. 


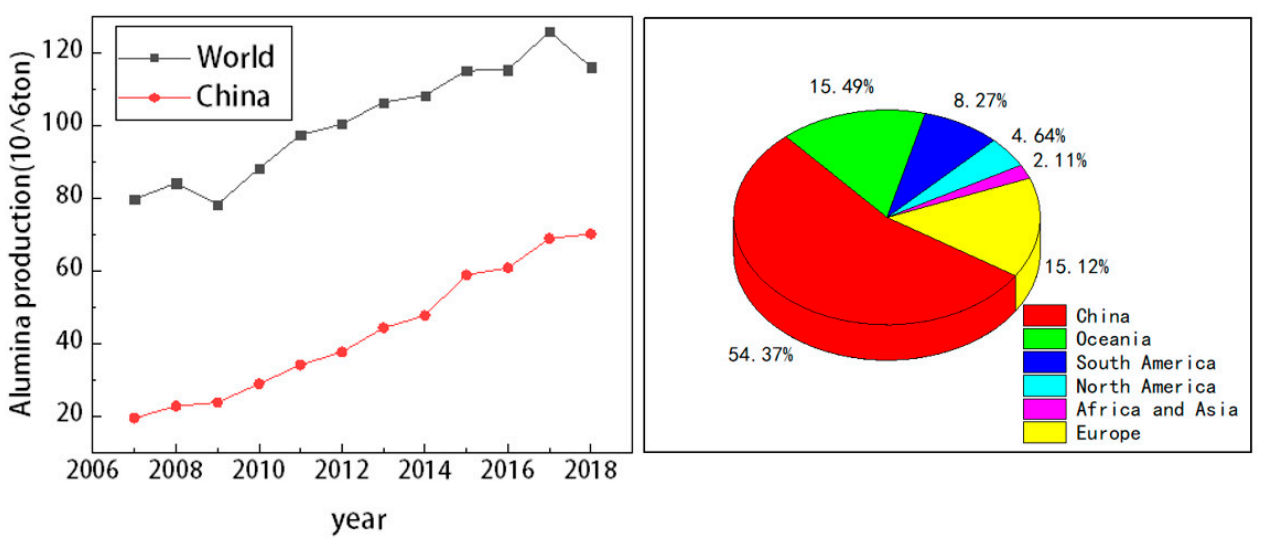

Figure 1. Global data from the International Aluminium Institute regarding annual alumina production worldwide and in China. Regional distribution of alumina production in 2017 [5-8]. Reproduced with permission from [5], published by Elsevier B.V., 2016.

RM has not been applied in large quantities until now because of its high alkalinity, technical and economic cost restrictions, industrial conditions, public consideration of its toxicity leaching, and market demand [9]. Moreover, the chemical and mineral components of RM widely vary depending on the origin and processing conditions of bauxite. Therefore, no unified method and standards are available for RM treatment [10]. Thus, RM is mainly stored in dams. Large areas of RM storage occupy considerable land resources and seriously pollute the environment [11].

Methods for the safe treatment and disposal of RM are urgently needed [12]. At present, the treatment and utilization of RM are mainly concentrated on metal recovery, adsorbents, catalysis, building materials, and other aspects [13]. The comprehensive utilization rate of RM is less than $4 \%$ in China, indicating that a major proportion of RM is unutilized [14].

RM exhibits a small particle size (particle diameter of 0.075-0.005 $\mathrm{mm}$ accounts for about $90 \%$ ) but large specific surface area $\left(40-70 \mathrm{~m}^{2} / \mathrm{g}\right)$ and high chemical reactivity, which benefit the adsorption of metal ions [15]. Moreover, the small amounts of $\mathrm{Ca}^{2+}$ and $\mathrm{Mg}^{2+}$ in $\mathrm{RM}$ can easily precipitate with soluble carbonate in strong alkaline solutions, thereby providing additional adsorption sites for toxic trace elements in adsorption solutions [16]. The relatively strong alkalinity of RM can decrease the mobility of heavy metal ions, which is highly suitable for adsorption to remove toxic and harmful ions in sewage, soil (such as $\mathrm{Pb}^{2+}, \mathrm{Cr}^{3+}, \mathrm{As}^{3+}$, and $\mathrm{F}^{-}$), and corrosive gases in waste (such as $\mathrm{SO}_{2}$ and $\mathrm{NO}_{2}$ ) [17]. The harmful effects of $\mathrm{RM}$ on the environment can be effectively reduced by transforming RM into absorbent and other useful products [18]. This review summarizes the composition and basic properties of RM and enumerates the applications of RM in environmental restoration, thereby providing a reference for the environmental protection and effective utilization of RM.

\section{Properties of RM}

The composition and properties of RM depend on bauxite ore sources and alumina production processes [19]. The composition and corresponding physical and chemical properties of RM vary depending on the different production methods of alumina and producing areas of raw materials. Table 1 lists the chemical compositions of RM using different production processes (Bayer, sintering, and combined Bayer-sintering process) [19].

The composition of RM is affected by the chemical composition of bauxite and the production of alumina. The main components of $\mathrm{RM}$ are $\mathrm{Fe}_{2} \mathrm{O}_{3}, \mathrm{Al}_{2} \mathrm{O}_{3}, \mathrm{SiO}_{2}, \mathrm{CaO}, \mathrm{Na}_{2} \mathrm{O}$, and $\mathrm{TiO}_{2}$, which account for approximately $85 \%$ of RM [20]. RM produced by the Bayer method has a much higher content of $\mathrm{Fe}_{2} \mathrm{O}_{3}$ than that produced by the combined process. RM produced by sintering has a significantly higher content of $\mathrm{Al}_{2} \mathrm{O}_{3}$ than that produced by the combined Bayer-sintering process. Meanwhile, RM produced by the combined Bayer-sintering process has a significantly higher content of $\mathrm{SiO}_{2}$ than that produced by the Bayer process. However, the content of $\mathrm{SiO}_{2}$ produced by the combined 
Bayer-sintering process was lower than that prepared by the Bayer method. Moreover, decaying components and trace nonferrous metals, such as rhenium, gallium, yttrium, scandium, tantalum, niobium, uranium, thorium, and lanthanide elements, have been observed in RM [21]. The main environmental hazard factor of $\mathrm{RM}$ is its $\mathrm{Na}_{2} \mathrm{O}$ supernatant. The added solution contains $2-3 \mathrm{~g} / \mathrm{L}$ alkali and has $\mathrm{pH} 13-14$. The main components are $\mathrm{K}, \mathrm{Na}, \mathrm{Ca}, \mathrm{Mg}, \mathrm{Al}, \mathrm{OH}^{-}, \mathrm{F}^{-}, \mathrm{Cl}^{-}$, and SO${ }^{2-4}$ [22].

Table 1. Chemical compositions of RM using different production methods (\%). Reproduced with permission from [23], published by Elsevier Ltd., 2017.

\begin{tabular}{cccccccccccc}
\hline $\begin{array}{c}\text { Chemical } \\
\text { Constituent }\end{array}$ & $\mathrm{Fe}_{\mathbf{2}} \mathrm{O}_{\mathbf{3}}$ & $\mathrm{Al}_{\mathbf{2}} \mathbf{O}_{\mathbf{3}}$ & $\mathrm{SiO}_{\mathbf{2}}$ & $\mathrm{CaO}$ & $\mathrm{Na}_{\mathbf{2}} \mathbf{O}$ & $\mathrm{TiO}_{\mathbf{2}}$ & $\mathbf{K}_{\mathbf{2}} \mathrm{O}$ & $\mathbf{M g O}$ & $\mathrm{Sc}_{\mathbf{2}} \mathrm{O}_{\mathbf{3}}$ & $\mathbf{N b}_{\mathbf{2}} \mathrm{O}_{\mathbf{5}}$ & Loss \\
\hline Bayer process & 13.69 & 7.02 & 18.10 & 42.21 & 2.38 & 2.1 & 0.30 & - & - & - & - \\
Combined process & 10.97 & 7.68 & 22.67 & 40.78 & 2.93 & 3.26 & 0.38 & 1.77 & - & - & 11.77 \\
Sintering process & 11.4 & 10.66 & 21.06 & 40.62 & 1.49 & - & 0.45 & 0.93 & - & - & 6.86 \\
\hline
\end{tabular}

Table 2 lists the mineral compositions of RM produced using different methods. As shown in the table, the active component of $\beta-2 \mathrm{CaO} \cdot \mathrm{SiO}_{2}$ in the sintering and combined $\mathrm{RM}$ accounts for approximately $50 \%$ of the total mass. These two kinds of RM can be directly used in the production of building materials. The main mineral groups in the Bayer RM are aluminum sodium silicate, hydrated garnet, calcite, and monohydrated soft bauxite, with high iron content.

Table 2. Mineral composition of RM $(\%, \omega)$. Reproduced with permission from [23], published by Elsevier Ltd., 2017.

\begin{tabular}{|c|c|c|c|}
\hline Mineral Composition (Chemical Formula) & Sintering Process & Combined Process & Bayer Process \\
\hline$\beta-2 \mathrm{CaO} \cdot \mathrm{SiO}_{2}$ & 46 & 43 & - \\
\hline $\begin{array}{l}\text { Sodium aluminosilicate } \\
\left(\mathrm{Na}_{2} \mathrm{O} \cdot \mathrm{Al}_{2} \mathrm{O}_{3} \cdot 1.7 \mathrm{SiO}_{2} \cdot \mathrm{nH}_{2} \mathrm{O}\right) \cdot \mathrm{NaX} \text { or } \mathrm{Na}_{2} \mathrm{X}\end{array}$ & 4 & 4 & 20 \\
\hline $\begin{array}{l}\text { Anorthite } 3 \mathrm{CaO} \cdot \mathrm{Al}_{2} \mathrm{O}_{3} \cdot 3 \mathrm{Si}_{2} \mathrm{O}_{2} \text { or } \\
3 \mathrm{CaO} \cdot \mathrm{Al}_{2} \mathrm{O}_{3} \cdot x \mathrm{SiO}_{2} \cdot(6-2 x) \mathrm{H}_{2} \mathrm{O}\end{array}$ & 5 & 2 & 20 \\
\hline Calcite $\mathrm{CaCO}_{3}$ & 14 & 14 & 19 \\
\hline Limonite $\mathrm{Fe}_{2} \mathrm{O}_{3} \cdot \mathrm{H}_{2} \mathrm{O}$ & 7 & 4 & 4 \\
\hline Boehmite $\mathrm{Al}_{2} \mathrm{O}_{3} \cdot \mathrm{H}_{2} \mathrm{O}$ & - & 1 & 21 \\
\hline Perovskite $\mathrm{CaO} \cdot \mathrm{TiO}_{2}$ & 7 & 12 & 15 \\
\hline $4 \mathrm{CaO} \cdot \mathrm{Al}_{2} \mathrm{O}_{3} \cdot \mathrm{Fe}_{2} \mathrm{O}_{3}$ & 8 & 12 & - \\
\hline $\mathrm{Na}_{2} \mathrm{O} \cdot \mathrm{Al}_{2} \mathrm{O}_{3} \cdot 2 \mathrm{SiO}_{2}$ & 7 & 8 & - \\
\hline $\mathrm{FeS}_{2}$ & 1 & - & - \\
\hline Others & 1 & - & 1 \\
\hline Total & 100 & 100 & 100 \\
\hline
\end{tabular}

Various alumina production processes are used for different bauxite types worldwide due to several mineral compositions and grades (Table 3). The Australian and Indian bauxite are trihydrous and monohydrous soft bauxite, which are produced by the Bayer process. The samples from Shandong, Henan, and Shanxi adopt sintering, Bayer, and combined RM, respectively. The main components, including $\mathrm{Al}_{2} \mathrm{O}_{3}, \mathrm{Fe}_{2} \mathrm{O}_{3}, \mathrm{SiO}_{2}, \mathrm{CaO}, \mathrm{Na}_{2} \mathrm{O}$, and $\mathrm{TiO}_{2}$ of $\mathrm{RM}$ from different sources are basically the same. However, the iron content in $\mathrm{RM}$ in China is considerably lower than those in Australia and India. In addition, the contents of $\mathrm{Fe}_{2} \mathrm{O}_{3}, \mathrm{Al}_{2} \mathrm{O}_{3}$, and $\mathrm{Na}_{2} \mathrm{O}$ in Bayer $\mathrm{RM}$ are higher than those in the sintering or combined method. Moreover, the contents of $\mathrm{CaO}$ and $\mathrm{SiO}_{2}$ are relatively low. Furthermore, substantial metal oxide keeps the $\mathrm{pH}$ of $\mathrm{RM}$ between 12 and 14 . 
Table 3. Major chemical components of RM worldwide (mass fraction \%). Reproduced with permission from [23], published by Elsevier Ltd., 2017.

\begin{tabular}{cccccccccccc}
\hline $\begin{array}{c}\text { Chemical } \\
\text { Constituent }\end{array}$ & $\mathrm{Fe}_{2} \mathrm{O}_{3}$ & $\mathrm{Al}_{2} \mathrm{O}_{3}$ & $\mathrm{SiO}_{2}$ & $\mathrm{CaO}$ & $\mathrm{Na}_{2} \mathrm{O}$ & $\mathrm{TiO}_{2}$ & $\mathrm{~K}_{2} \mathrm{O}$ & $\mathbf{M g O}$ & $\mathrm{Sc}_{2} \mathrm{O}_{3}$ & $\mathbf{N b}_{2} \mathrm{O}_{5}$ & Loss \\
\hline Bayer process & 13.69 & 7.02 & 18.10 & 42.21 & 2.38 & 2.1 & 0.30 & - & - & - & - \\
Combined process & 10.97 & 7.68 & 22.67 & 40.78 & 2.93 & 3.26 & 0.38 & 1.77 & - & - & 11.77 \\
Sintering process & 11.4 & 10.66 & 21.06 & 40.62 & 1.49 & - & 0.45 & 0.93 & - & - & 6.86 \\
\hline
\end{tabular}

A scanning electron microscope is used to characterize and observe RM [24-26]. RM exhibits strong alkaline composition, complex properties, and abundant metal oxides. Moreover, RM particles show uniform dispersion, thereby indicating that RM has a large specific surface area $\left(40-70 \mathrm{~m}^{2} / \mathrm{g}\right)$, porous characteristics (void ratio $=2.53-2.95$, average pore size $=2.98-3.82 \mathrm{~nm}$ ), and excellent stability in aqueous solution [27]. These characteristics render RM suitable as an adsorbent. Applying RM adsorbents in wastewater, waste gas, and soil restoration not only overcomes the negative effect of RM accumulation on the environment but also contributes to environmental restoration.

\section{Application in Water Treatment}

Increased industrial and agricultural activities result in the production of various toxic pollutants, which are the major cause of water pollution worldwide. The types of contaminants in wastewater are mainly determined by the nature of the industry. However, the pollutants commonly found in wastewater are metal and non-metal ions, phenols, and various dyes. The pollutants in wastewater are toxic to aquatic organisms and may cause natural water to be unsuitable for drinking and growing crops. Various methods, such as coagulation, foam flotation, filtration, ion exchange, aerobic and anaerobic treatment, advanced oxidation process, solvent extraction, adsorption, electrolysis, microbial reduction, and activated sludge, have been employed in wastewater treatment [28]. Compared with the more conventional methods, flotation offers several advantages, such as higher metal selectivity, higher removal efficiency, higher over flow rates, lower detention periods, lower operating cost, and production of more concentrated sludge [29]. However, the disadvantages of flotation include high initial capital cost and high maintenance and operation costs Electrochemical technology for heavy metal removal from wastewater is a rapid and well-controlled method that requires few chemicals, provides good reduction yields, and produces less sludge. However, the development of electrochemical technologies is restricted by their high initial capital investment and expensive electricity supply. Membrane filtration can remove heavy metal ions with high efficiency, but its high cost, process complexity, membrane fouling, and low permeate flux limit its use in heavy metal removal [30]. The sludge produced when using coagulation flocculation to remove heavy metals from wastewater features good settling and dewatering characteristics [31]. However, this method involves chemical consumption and increased sludge volume generation. In a word, these technologies demonstrate evident shortcomings, including inadequate removal of pollutants [32], high capital costs [33], considerable reagents or energy requirements [34], and generation of toxic sludge or other wastes requiring further safe disposal [35]. Adsorption is a common process in wastewater treatment technologies. RM, a type of industrial waste with low cost and strong adsorption, is used to treat wastewater discharged by various industries and could provide substantial advantages for environmental pollution control. RM can be used as an adsorbent to remove different pollutants from wastewater, as shown in Figure 2. Prior to water treatment, RM should be first activated by acidification, thermal activation, and synthesis to prevent secondary pollution to water and enhance its adsorption capacity [36]. 


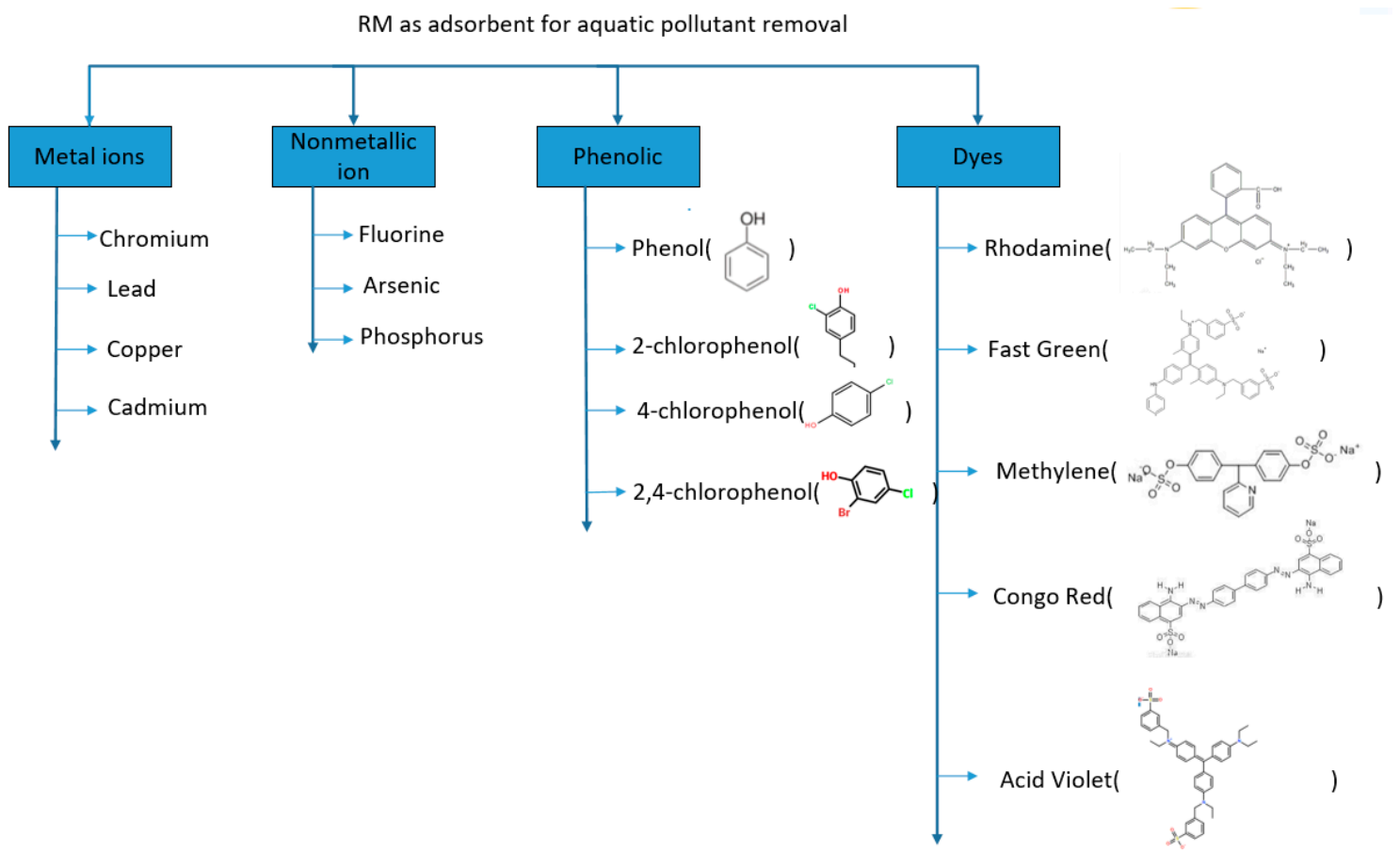

Figure 2. RM as adsorbent for the removal of aquatic pollutants from wastewater. Reproduced with permission from [37], published by Taylor \& Francis, 2011.

\subsection{Removal of Metal Ions from Water}

Metal ions are aquatic pollutants that pose a serious threat to human health worldwide. The use of RM for metal ion removal from water has been widely explored by various researchers.

\subsubsection{Removal of Chromium (Cr)}

The element $\mathrm{Cr}$ should not be ignored because $\mathrm{Cr}^{6+}$ compounds are toxic owing to their high water solubility and mobility.

Some researchers explored the use of RM as an adsorbent for the removal of $\mathrm{Cr}$ from aqueous solutions [38]. Activated RM (ARM) has been investigated as an adsorbent for $\mathrm{Cr}^{6+}$ removal from industrial effluents. ARM was prepared by acid dissolution and then treated by ammonia precipitation [38,39]. The Langmuir monolayer capacity of ARM for $\mathrm{Cr}^{6+}$ is $30.74 \mathrm{mmol} / \mathrm{g}$. The adsorption of competing anions on ARM is in the order of $\mathrm{PO}_{4}{ }^{3-}>\mathrm{SO}_{4}{ }^{2-}>\mathrm{NO}_{3}{ }^{-}$. Cr is removed from RM activated by hydrochloric acid, and the removal efficiency of chromate is approximately $70 \%$ by the optimal $\mathrm{pH}$ value of RM. Kim et al. used $\mathrm{RM}$ to remove $\mathrm{Cr}^{3+}$ from synthetic wastewater [39] and found that the maximum adsorption efficiency is $99.9 \%$ when $1.5 \mathrm{~g}$ of RM is used to remove $\mathrm{Cr}$ from the solution containing $150 \mathrm{mg} \mathrm{Cr}{ }^{3+} / 100 \mathrm{~mL}$.

$\mathrm{Li}$ et al. showed that the hydrated garnet $\left(3 \mathrm{CaO} \cdot \mathrm{Al}_{2} \mathrm{O}_{3} \cdot \mathrm{SiO}_{2} \cdot 4 \mathrm{H}_{2} \mathrm{O}\right)$ in the original $\mathrm{RM}$ decomposes into $\mathrm{Ca}_{2} \mathrm{Al}_{2} \mathrm{SiO}_{7}$ and $\mathrm{Ca}_{3} \mathrm{Al}_{2} \mathrm{O}_{6}$ at high temperatures and that $\mathrm{CaCO}_{3}$ is fully decomposed [40]. These changes in metal phase enhance the activity of RM in water and heighten the effect of $\mathrm{Cr}^{6+}$ adsorption [40]. The modification of RM-adsorbed $\mathrm{Cr}^{6+}$ is mainly static gravitational pull. RM loses surface, hydration, and bound water in the roasting process. The resistance of $\mathrm{RM}$ to adsorb $\mathrm{Cr}^{6+}$ is decreased, but the surface roughness of RM particles is improved. In addition, specific surface area is increased to provide substantial active sites.

Sahu et al. studied the adsorption of $\mathrm{Cr}^{6+}$ on $\mathrm{RM}$ activated by $\mathrm{H}_{2} \mathrm{O}_{2}$ at $500{ }^{\circ} \mathrm{C}$ [41]. Results showed that ARM exhibits notable adsorption performance on $\mathrm{Cr}$ and could effectively remove $\mathrm{Cr}^{6+}$ in water in various concentrations, and the removal rate of $\mathrm{Cr}^{6+}$ reaches $87.65 \%$. An experimental study on the adsorption column showed that RM has an industrial application value as an adsorbent. The 
adsorption column can be directly treated with $\mathrm{HNO}_{3}$ to desorb the adsorbed metal. The adsorbent can be reused, and the presence of salt in wastewater does not affect the adsorption process.

The use of $\mathrm{RM} /$ carbon material to recycle $\mathrm{Cr}^{6+}$ from wastewater has been studied [36,38], and chromite $\left(\mathrm{FeCr}_{2} \mathrm{O}_{4}\right)$ has been produced. The $\mathrm{RM} /$ carbon material was prepared by mixing $\mathrm{RM}$ pulverized coal by carbon heat treatment, which is a cheap and effective $\mathrm{Cr}^{6+}$ removal agent. During this process, $\mathrm{Fe}_{2} \mathrm{O}_{3}$ is decreased to nano-zerovalent iron (nZVI) in RM, and several components, such as $\mathrm{Al}_{2} \mathrm{O}_{3}$ and $\mathrm{SiO}_{2}$, from $\mathrm{RM}$ act as dispersants and stabilizers of nZVI. The nZVI materials play a vital role in $\mathrm{Cr}$ removal, and the nZVI particles are corroded as observed via transmission electron microscopy to form the core-shell or hollow nanoparticles (Figure 3A). The main component of the core-shell or hollow nanoparticles is iron oxide [42]. The valence state of $\mathrm{Cr}$ species of used $\mathrm{RM} /$ carbon was analyzed by XPS. In addition, $\mathrm{Cr}^{6+}$ was diminished and collected in the form of $\mathrm{Cr}^{3+}$ on the surface with the addition of RM/carbon. Scanning electron microscopy (SEM)-EDS showed that $\mathrm{Cr}$-Fe hydroxides are first co-precipitated, and their typical morphological characteristics are shown in Figure 3B [43]. In addition, the $\mathrm{pH}$ is increased from 3.0 to 6.8 of the solution with $\mathrm{Cr}^{6+}$ removal (Figure 3C). In summary, $\mathrm{nZVI}$ is dissolved as $\mathrm{Cr}^{6+}$ is decreased to generate $\mathrm{Cr}^{3+}$ and $\mathrm{Fe}^{6+}$ at a low $\mathrm{pH}$. However, this approach requires substantial $\mathrm{H}^{+}$, thereby resulting in a rapid increase in $\mathrm{pH}$. The increase in solution $\mathrm{pH}$ prevents the dissolution of nZVI and the reduction of $\mathrm{Cr}^{6+}$. Nevertheless, the collection of $\mathrm{Cr}-\mathrm{Fe}$ hydroxides precipitated on $\mathrm{RM} /$ carbon is promoted to remove $\mathrm{Cr}^{6+}$ and dissolve $\mathrm{Fe}$ ions from the wastewater. The results show that solution $\mathrm{pH}$ greatly affects the $\mathrm{RM} /$ carbon removal of $\mathrm{Cr}^{6+}$ from wastewater. The initial $\mathrm{pH}$ of 3.0 may maintain a balance between the reduction of $\mathrm{Cr}^{6+}$ to $\mathrm{Cr}^{3+}$ and subsequent precipitation of the generated $\mathrm{Cr}^{3+}$ and $\mathrm{Fe}^{3+}$ ions (Figure 3C). The removal efficiency of $\mathrm{Cr}^{6+}$ with $\mathrm{RM} /$ carbon at a constant $\mathrm{pH}$ of 3.0 is illustrated in Figure 3D. The removal efficiency of $\mathrm{Cr}^{6+}$ decreases from $15.4 \%$ to $12.7 \%$ within $5 \mathrm{~h}$ and remains at approximately $12.2 \%$ [44].
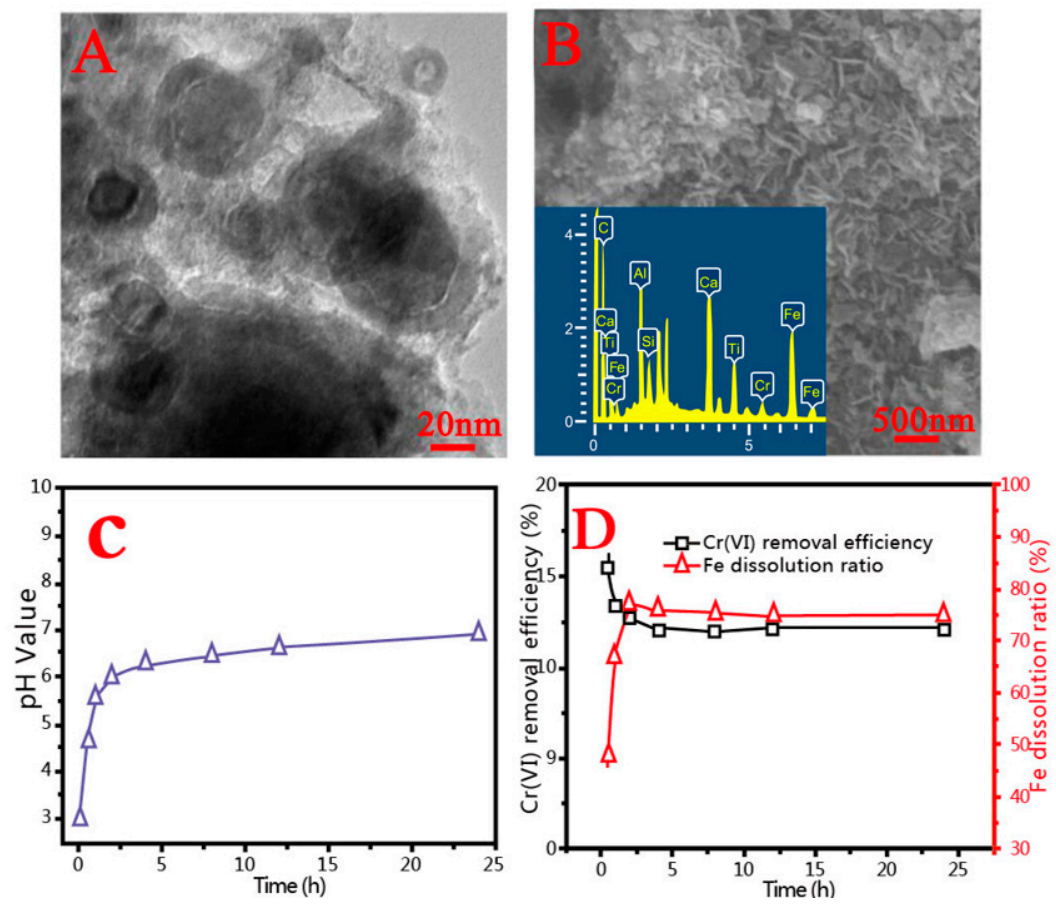

Figure 3. TEM (A) and SEM-EDS (B) images of the spent RM/carbon sample; $\mathrm{pH}$ and time during the removal process of $\mathrm{Cr}^{6+}$ over $\mathrm{RM} /$ carbon at the initial $\mathrm{pH}$ of $3.0(\mathrm{C})$; and removal efficiency of $\mathrm{Cr}^{6+}$ and dissolution rate of Fe over RM/carbon at the constant $\mathrm{pH}$ of 3.0 (D) $[40,44]$. Reproduced with permission from [40], published by Elsevier B.V., 2018.

The presented material/method exhibits various advantages, such as utilization of RM waste, low material cost, high nZVI activity, and facile carbothermal regeneration of the spent sample. Meanwhile, 
$\mathrm{FeCr}_{2} \mathrm{O}_{4}$ with approximately $30 \mathrm{wt}$. $\% \mathrm{Cr}_{2} \mathrm{O}_{3}$ content is regarded as a high-grade mineral resource and exhibits important industrial applications. In conclusion, $\mathrm{Cr}$ is recovered and utilized in wastewater, $\mathrm{RM}$ solid waste is recycled, and valuable $\mathrm{FeCr}_{2} \mathrm{O}_{4}$ is produced.

\subsubsection{Removal of Lead $(\mathrm{Pb})$}

The element $\mathrm{Pb}$ can hinder the formation of blood cells and accumulate in the human body, resulting in chronic poisoning. Moreover, this element can penetrate the brain tissue through blood and cause brain injury. The state stipulates that the content of $\mathrm{Pb}$ in the referenced water should be less than $0.05 \mathrm{mg} / \mathrm{L}$ [45].

Yu explored the removal of $\mathrm{Pb}$ from aqueous solutions using RM [46]. The effects of different reaction temperatures on $85 \%$ adsorbent (the mass ratio of $\mathrm{RM}$, clay, and coal powder is $85: 20: 5$ ) was investigated to remove $\mathrm{Pb}^{2+}$ in simulated wastewater [47]. At the temperatures of $20{ }^{\circ} \mathrm{C}, 30^{\circ} \mathrm{C}$, and $40{ }^{\circ} \mathrm{C}$ and reaction time of $3 \mathrm{~h}$, the removal rates of $\mathrm{Pb}^{2+}$ are $60.4 \%, 82.6 \%$, and $60.4 \%$, respectively, when the initial concentration of $\mathrm{Pb}$ is $50 \mathrm{mg} / \mathrm{L}$ [46]. Chen et al. studied the effect of RM-adsorbed $\mathrm{Pb}$ ions in water [45]. The results showed that RM has excellent adsorption of $\mathrm{Pb}$ ions [46]. When the addition amount of $\mathrm{RM}$ reaches $2 \mathrm{~g} / \mathrm{L}$, the $\mathrm{Pb}^{2+}$ removal rate reaches $99.6 \%$ [47]. Moreover, temperature exerts a notable effect on adsorption. An increase in temperature causes a faster adsorption rate. This condition indicates that the adsorption reaction of $\mathrm{RM}$ on $\mathrm{Pb}^{2+}$ is chemical adsorption, and the adsorption process requires an activation energy. Therefore, the adsorption rate can be improved by increasing the temperature [48]. Increasing the temperature can overcome the activation energy of the reaction and promote the adsorption reaction; increasing the temperature also increases the molecular thermal motion in the system and facilitates the adsorption reaction.

\subsubsection{Removal of Copper $(\mathrm{Cu})$}

The element $\mathrm{Cu}$ is found in wastewater from smelting, metal processing, machine manufacturing, organic synthesis, and other industries in China, with the highest amount of $\mathrm{Cu}$ discharged from metal processing and electroplating plants, which contain dozens to hundreds of milligrams per liter of $\mathrm{Cu}$ [49]. This type of wastewater discharge seriously affects the quality of water body. Cu content of $0.01 \mathrm{mg} / \mathrm{L}$ of water can evidently inhibit water self-purification [50], whereas $\mathrm{Cu}$ contents exceeding $3.0 \mathrm{mg} / \mathrm{L}$ generates a certain odor [51]. If wastewater containing $\mathrm{Cu}$ is used to irrigate the farmland, the $\mathrm{Pb}$ accumulation of $\mathrm{Cu}$ in soil and crops will cause poor crop growth [52]. The critical concentration of $\mathrm{Cu}$ in irrigation water is $0.6 \mathrm{mg} / \mathrm{L}$ [53]. The high content of $\mathrm{Cu}$ ions can contaminate plants and indirectly cause harm to human beings [54].

Yu et al. explored the removal of $\mathrm{Cu}$ from aqueous solutions using RM [55]. In the adsorption process, the concentration of $\mathrm{Cu}^{2+}$ in solution gradually decreases with prolonged adsorption time. On the contrary, the solution $\mathrm{pH}$ gradually increases because of the dissolution of alkaline substances in RM. The interaction between $\mathrm{RM}$ and $\mathrm{Cu}^{2+}$ is not only adsorption but also precipitation. Moreover, the $\mathrm{Cu}^{2+}$ removal rate gradually increases with increasing $\mathrm{pH}$ and then reaches equilibrium with the extension of time. The initial adsorption rates at 1.5 and $2 \mathrm{pH}$ are considerably lower than those at $\mathrm{pH} 2.5$ and 3. This result can be ascribed to the high $\mathrm{H}^{+}$concentration of the $\mathrm{RM}$ adsorbent in the solution. Under the low $\mathrm{pH}$ condition, the high concentration of $\mathrm{H}^{+}$in the solution promotes the protonation of functional groups on the adsorbent's surface, the positive downward charge increases on the adsorbent's surface, and the removal rate of $\mathrm{Cu}^{2+}$ is decreased in the solution [56].

\subsubsection{Removal of Cadmium (Cd)}

The element $\mathrm{Cd}$ is an industrial and environmental pollutant, and its main sources are $\mathrm{Zn}, \mathrm{Cu}$, and $\mathrm{Pb}$ smelting, electroplating, battery, alloy, paints and plastics, and other industrial productions [57]. Moreover, $\mathrm{Cd}$ is a toxic element in the human body. Numerous researchers proposed in the last century $60 \mathrm{~s} \mathrm{Cd}$ pollution due to Japan's "pain pain disease," and the relationship between environmental Cd pollution and public health has received increasing attention from people. 
Duan et al. explored the removal of $\mathrm{Cd}$ from aqueous solutions using $\mathrm{RM}$ activated by $\mathrm{H}_{2} \mathrm{O}_{2}$ [58]. In the $\mathrm{pH}$ range of $2-12, \mathrm{Cd}$ mainly exists in the solution in four forms $\left(\mathrm{Cd}^{2+}, \mathrm{Cd}^{+}, \mathrm{Cd}(\mathrm{OH})_{2}\right.$, and $\left.\mathrm{Cd}(\mathrm{OH})_{3}{ }^{-}\right)$[58]. Therefore, the adsorption forms are different under various $\mathrm{pH}$ conditions. In this process, the adsorption mechanism of the $\mathrm{RM}$ adsorbent on $\mathrm{Cd}^{2+}$ is analyzed as follows:

When the $\mathrm{pH}$ is between 2.5 and $6, \mathrm{Cd}$ in the solution mainly exists in the form of $\mathrm{Cd}^{2+}$, and its main action mechanism with RM adsorbent is as follows:

$$
\begin{aligned}
& \mathrm{H}^{+}+\equiv \mathrm{Fe}-\mathrm{OH}=\mathrm{Fe}-\mathrm{OH}_{2}{ }^{+}, \\
& \mathrm{Cd}^{2+}+\equiv \mathrm{Fe}-\mathrm{OH}_{2}{ }^{+}=\equiv \mathrm{Fe}-\mathrm{OCd}^{+}+2 \mathrm{H}^{+}, \\
& \mathrm{Cd}(\mathrm{OH})^{+}+\equiv \mathrm{Fe}-\mathrm{OH}_{2}{ }^{+}=\mathrm{Fe}-\mathrm{OCd}(\mathrm{OH})^{0}+2 \mathrm{H}^{+} \text {. }
\end{aligned}
$$

When the $\mathrm{pH}$ is between 6.0 and 7.5 , the four forms of $\mathrm{Cd}$ simultaneously exist.

$$
\begin{gathered}
\mathrm{Cd}(\mathrm{OH})^{+}+\equiv \mathrm{Fe}^{-\mathrm{OH}_{2}}{ }^{+}=\mathrm{Fe}-\mathrm{OCd}(\mathrm{OH})^{0}+2 \mathrm{H}^{+}, \\
\mathrm{Cd}(\mathrm{OH})_{2}{ }^{0}+\equiv \mathrm{Fe}_{-} \mathrm{OH}_{2}{ }^{+}=\mathrm{Fe}-\mathrm{OCd}(\mathrm{OH})_{2}{ }^{-}+2 \mathrm{H}^{+},
\end{gathered}
$$

where $\mathrm{Fe}-\mathrm{OH}_{2}{ }^{+}$is the protonation site, and $\mathrm{Fe}-\mathrm{OCd}(\mathrm{OH})^{0}$ and $\mathrm{Fe}-\mathrm{OCd}(\mathrm{OH})_{2}{ }^{-}$are the compounds formed on the surface of the RM adsorbent. In addition, the surface of the RM adsorbent is negatively charged and exhibits a large specific surface area. Therefore, part of $\mathrm{Cd}^{2+}$ is absorbed to the surface of the adsorbent through electrostatic neutralization during adsorption. Some $\mathrm{Cd}^{2+}$ is retained inside the adsorbent by pore adsorption. In summary, electrostatic attraction, pore adsorption, and surface chemical reactions are mainly found in the adsorption of the RM adsorbent on $\mathrm{Cd}^{2+}$.

Guo et al. studied the use of RM to remove Cd in wastewater by electrostatic attraction [59]. Results show that RM exhibits an excellent adsorption performance to $\mathrm{Cd}$ ions, and the adsorption rate reaches $95.32 \%$. The $\mathrm{pH}$ value considerably influences the adsorption effect of $\mathrm{RM}$ on $\mathrm{Cd}$ ions; the higher the $\mathrm{pH}$, the faster the removal rate. This condition is due to the high negative charge and strong acid condition $\mathrm{H}^{+}$concentrated on the $\mathrm{RM}$ surface, but the $\mathrm{Cd}$ ions are blocked, thereby resulting in a low removal rate. Wang et al. studied the use of the sintering method of RM particle adsorption agent (GS) to remove Cd [60]. They found that the maximum removal rate of GS on Cd (II) is $100 \%$. Adsorption is mainly dependent on the surface adsorption mechanism and electrostatic attraction of hydroxyl iron, and its adsorption process is in accordance with the pseudo two-stage kinetic model $\left(\mathrm{R}_{2}>0.999\right)$ [61].

At present, RM treated with heavy metals as an adsorbent is mainly in powder form. The powder particles of RM are very small with a specific surface area of $40-70 \mathrm{~m}^{2} / \mathrm{g}$. Thus, they can easily absorb other substances, resulting in a high adsorption performance, but are non-conducive to industrial application. The wastewater generated in the activation of powder RM is difficult to treat. In addition, the powder RM is difficult to recover and regenerate after the experiment. Liang et al. proposed a new granulation RM (GRM) adsorbent [62] under controlled experimental conditions at a desired concentration of $\mathrm{Cd}$ solution and $\mathrm{pH}$. GRM of about $10 \mathrm{~g}$ was added to $100 \mathrm{~mL}$ of Cd solution in a conical bottle. The bottles were placed in a vibrator under controlled temperature for $24 \mathrm{~h}$. The adsorption experiments were conducted at $30^{\circ} \mathrm{C}, 40^{\circ} \mathrm{C}$, and $50^{\circ} \mathrm{C}$. After completion of adsorption, the solution was filtered directly. The adsorption property of GRM to $\mathrm{Cd}^{2+}$ in aqueous solution was also studied, the process is shown in Figure 4. On the basis of the pore adsorption and surface chemical reaction of the RM adsorbent to $\mathrm{Cd}^{2+}$ experiments, GRM exhibits a strong adsorption capacity for $\mathrm{Cd}^{2+}$ and is suitable for industrial applications. 


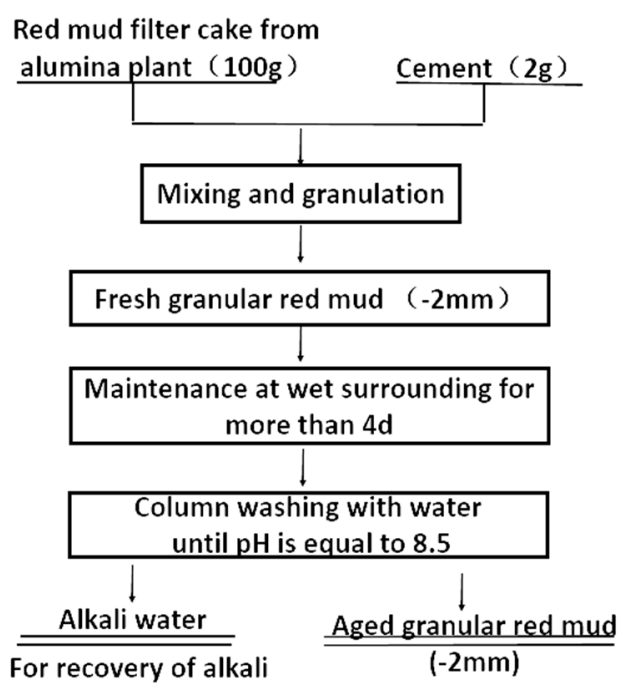

Figure 4. Preparation procedure of granular red mud (GRM) adsorbent [63]. Reproduced with permission from [63], published by The Transactions of Nonferrous Metals Society of China, 2012.

\subsection{Removal of Non-Metallic Ions}

\subsubsection{Removal of Fluorine (F)}

The methods for removing excessive fluorinated substances in water include adsorption, ion exchange, precipitation, electrolysis, and electrodialysis. RM can be used as a cheap adsorbent for the removal of fluoride in wastewater.

The ability of ARM activated by $\mathrm{HCl}$ to adsorb $\mathrm{F}$ is higher than that of raw $\mathrm{RM}$, and the adsorption rate is high (82\%) [64]. The adsorption process is consistent with the Langmuir isothermal model. Activation energy can increase the specific surface area and affect the binding sites of RM to improve the adsorption capacity. The adsorption capacity of $\mathrm{RM}$ is affected when the $\mathrm{pH}$ values are greater than 5.5. Hydroxide and $\mathrm{F}$ ions in the solution form intense competition, and the removal rate of $\mathrm{F}$ is considerably decreased. The $\mathrm{F}$ ion adsorption decreases in acidic environment because of the formation of the weak electrolyte hydrofluoric acid. $\mathrm{RM}$ contains certain amounts of $\mathrm{CaO}, \mathrm{Al}_{2} \mathrm{O}_{3}$, and $\mathrm{Fe}_{2} \mathrm{O}_{3}$, and these compounds exert adsorption effects on $\mathrm{F}$. Such existence can accelerate the sedimentation rate of flocs, neutralize the alkalinity of RM in the treatment process, and make the effluent $\mathrm{pH}$ stable and reach the discharge standard. The $\mathrm{HCl}$ and high-temperature calcining activation can remove impurities in the RM channel and surface adsorption and bonded water in the skeleton to dredge the internal pores of RM and decrease the adsorption resistance of water film to ions, which promotes the diffusion and adsorption of RM.

Li et al. used the Bayer RM of Pingguo aluminum factory as the main raw material, which contains certain amounts of $\mathrm{Na}_{2} \mathrm{SiO}_{3} \cdot 9 \mathrm{H}_{2} \mathrm{O}, \mathrm{CaO}$, and carbon powder, and then prepared $\mathrm{RM}$ into balls for roasting [65]. The adsorption capacity is $0.47 \mathrm{mg} / \mathrm{g}$, and the $\mathrm{F}$ removal rate reaches $98 \%$. Song-jiang et al. used acid-ARM as the carrier and cerium oxide as the active component [66]. Then, a cerium-loaded adsorbent was prepared using RM. Under $25^{\circ} \mathrm{C}$ and static position, the fluoride removal rate can reach more than $98 \%$. Panda et al. studied the effects of modification and adsorption of $\mathrm{F}$ ions in wastewater by the Bayer method [67]. Results show that the effect of RM on the removal of $F$ ions in wastewater is evidently improved, thereby making it easy to be recycled.

\subsubsection{Removal of arsenic (As)}

The element As is highly toxic and widely used in industrial and agricultural production. The As pollution causes environmental problems, especially water contamination. Therefore, finding a method to remove As from water with complete, simple, and low-cost operation is necessary. Treating As-containing wastewater and purifying drinking water are of practical importance. 
Numerous researchers explored the removal of As from aqueous solutions using RM, which is a great choice. Yan et al. achieved great progress in the removal of As by using solid RM and acid ARM [68]. The removal of As from the liquid phase of RM (LPRM) by coprecipitation with aluminum hydroxide was further studied. The mixture of LPRM-arsenical solution was first neutralized with an acid solution by air-agitation. Then, the mixture was neutralized with $\mathrm{CO}_{2}$ gas. The effect of the volumetric ratio of LPRM:As ${ }^{5+}$-solution on the removal of $\mathrm{As}^{5+}$ by coprecipitation as aluminate in the LPRM was studied. Results showed that $\mathrm{As}^{5+}$ is effectively removed by LPRM with a volumetric LPRM: $\mathrm{As}^{5+}{ }^{5}$-solution ratio of 0.1 from an As solution. The removal of As from water by RM under different conditions was also studied. RM efficiently removed $\mathrm{As}^{3+}$ in the $\mathrm{pH}$ ranges of 7.6-9.0 and 5.5-6.0. With appropriate RM dosage, the residual As in solution is decreased below the regulated acceptable As limit $(0.1 \mathrm{mg} / \mathrm{L})$ from industrial wastes.

Activated seawater-neutralized RM (activated Bauxsol, AB) was used to remove inorganic As from water [69]. The $\mathrm{AB}$ was prepared by acid and heat treatment. Kinetic data indicated that the $\mathrm{As}^{5+}$ and $\mathrm{As}^{3+}$ achieve equilibration following pseudo-first-order kinetics. Within the range tested, the optimal $\mathrm{pH}$ for $\mathrm{As}^{5+}$ adsorption is 4.5, and the efficiency of $\mathrm{As}^{5+}$ removal is approximately $100 \%$, irrespective of the initial $\mathrm{As}^{5+}$ concentration. Accordingly, the optimum $\mathrm{pH}$ for $\mathrm{As}^{3+}$ removal is 8.5, and the removal efficiency changes with the initial $\mathrm{As}^{3+}$ concentration. The $\mathrm{As}^{5+}$ adsorption by $\mathrm{AB}$ can be well described using the FITEQL (v.4) and PHREEQC (v.2) computer programs.

RM can be used as an adsorbent of As because it has selective adsorption of arsenate ions, and $\mathrm{RM}$ with sorption of arsenate ions can be regenerated by acid or alkali. In industrial production, an integrated treatment system must be studied to remove harmful sediments. Therefore, the system should combine RM adsorption, activated carbon catalyst (oxidation of arsenate ions), and sulfide precipitation methods to form a complete treatment process for removing As from water.

\subsubsection{Removal of Phosphorous (P)}

ARM has an excellent ability of removing P. Li et al. prepared phosphorus-removing adsorbent with RM, which was activated by acid and roasting [70]. The saturated adsorption capacity values of acid- and roasting-ARM on P are 155.2 and $144.2 \mathrm{mg} / \mathrm{g}$, respectively. The adsorption efficiency of acid-ARM increases due to cleaning off the film that was attached to the surface of RM, thereby blocking the adsorption of $\mathrm{P}$ and dredging the internal pores of RM. The acidification process causes the erosion of the RM surface and roughness of the external surface. The specific surface area of RM increases from $14.09 \mathrm{~m}^{2} / \mathrm{g}$ to $21.76 \mathrm{~m}^{2} / \mathrm{g}$, thereby increasing the adsorption capacity. The increased adsorption efficiency of RM due to roasting activation leads to the disappearance of moisture, formation of micropores, and increase in specific surface area to $15.69 \mathrm{~m}^{2} / \mathrm{g}$.

Li et al. found that the adsorption of P by RM is a monomolecular layer [71]. The authors used ARM particles as the main raw material, fly ash as the activator, bentonite (soap soil) as the binder, and sodium bicarbonate as the foaming agent. The physical and chemical properties of the roasted RM particles were characterized and compared by infrared spectroscopy. Results show that the roasted $\mathrm{RM}$ particle surface can be formed with an - $\mathrm{OH}$ functional group structure of the material, which can occur with phosphoric acid root in the solution of the ligand exchange reaction and removal of phosphorus. Therefore, RM can effectively adsorb phosphorus in solution.

Zhang et al. used RM as a crystal seed to induce calcium phosphate (HAP) crystallization to recover phosphorus from simulated wastewater [72]. The recovery rate of $\mathrm{P}$ can reach $74.1 \%$. They also tried to add RM in the cementitious materials. The effect of RM on the phosphorus purification of ecological concrete was studied. The theoretical maximum phosphate adsorption capacity of RM is $36.76 \mathrm{mg} / \mathrm{g}$, which is greater than those of other adsorbents.

\subsection{Removal of Phenolic Pollutant}

Phenols are regarded as the priority pollutants in organic wastewater. Phenolic compounds are widely used in paper making, pesticides, dyes, textiles, medicine, plastics, rubber, leather making, and 
petroleum industries, domestic sewage, and decaying vegetation. Phenol and its derivatives are highly toxic and carcinogenic and must be removed before discharge. RM was used as a potential absorbent for removing phenolic substances from wastewater.

RM was used to remove phenol, 2- and 4-chlorophenol, and 2,4-dichlorophenol from wastewater [73,74]. The maximum adsorption condition of phenol and 2-chlorophenol occurs at $\mathrm{pH} 6.0$, whereas those of 4-chlorophenol and 2,4-dichlorophenol are achieved at pH 5.0 and 4.0, respectively. The adsorption amounts of RM on 2,4-dichlorophenol and 4-chlorophenol are $94.97 \%$ and $50.81 \%$, respectively. The researchers also conducted adsorption experiments on the mixtures of phenols and found that the adsorption capacity of 2,4-dichlorophenol is the largest compared with the other phenols. The order of adsorption is 2,4-dichlorophenol $>4$-chlorophenol $>2$-chlorophenol $>$ phenol, and the adsorption rates achieved are $97 \%, 93 \%, 80 \%$, and $51 \%$, respectively. At a flow rate of $0.5 \mathrm{~mL} / \mathrm{min}$ of column experiments, the removal rate of phenol and its derivatives in RM is up to $98 \%$.

The RM treated with hydrogen peroxide was studied by Gupta [75]. The result is the activated RM of phenol, and the removal rate of its derivatives (2- and 4-chlorophenol and 2,4-dichlorophenol) is $98 \%$ at $500{ }^{\circ} \mathrm{C}$. Thus, it can effectively remove phenol from wastewater. The SEM of activated RM can clearly show surface texture and porosity similar to poly-ferric-aluminum silicate. The RM adsorbs phenolic compounds because it has a positive surface charge that attracts negatively charged phenols. A summary of the adsorption capacity of RM for different phenolic pollutants is presented in Table 4 .

Table 4. Adsorption capacity of RM for the removal of phenolic pollutants from water [37,75-77]. Reproduced with permission from [37], published by Taylor \& Francis, 2011.

\begin{tabular}{cccc}
\hline Adsorbent & Adsorbate & Amount Adsorbed & Reference \\
\hline RM & Phenol & $0.63-0.74 \mathrm{~mol} / \mathrm{g}$ & {$[77]$} \\
RM & 2-Chlorophenol & $0.72-0.79 \mathrm{~mol} / \mathrm{g}$ & {$[77]$} \\
RM & 4-Chlorophenol & $0.78-0.82 \mathrm{~mol} / \mathrm{g}$ & {$[77]$} \\
RM & 2,4-Dichlorophenol & $0.80-0.85 \mathrm{~mol} / \mathrm{g}$ & {$[77]$} \\
Neutralized RM & Phenol & $2.50 \times 10^{-5} \mathrm{~mol} / \mathrm{g}$ & {$[75]$} \\
Acid-ARM & Phenol & $2.98 \times 10^{-5} \mathrm{~mol} / \mathrm{g}$ & {$[76]$} \\
\hline
\end{tabular}

\subsection{Removal of Dyes from Water}

Colored dye effluents are generally highly toxic to aquatic biota. Many human health-related problems, such as allergy, dermatitis, skin irritation, cancer, and mutations, are associated with dye pollution in water [78]. Textile industrial dyes are organic pollutants in water. The dyes do not usually undergo photodegradation and oxidative decomposition. Thus, the RM removal of dyes from wastewater is of great importance to water treatment.

Gupta et al. studied the removal of rhodamine B, fast green, and methylene blue dyes from wastewater by using RM [75]. The removal rates of the aforementioned compounds are 92.5, 94.0, and 75.0, respectively, and the optimal $\mathrm{pH}$ values for the compounds are 1.0, 7.0, and 8.0, respectively. During the column operation, the removal rate of the compounds is approximately $95-97 \%$, and the flow rate is $0.5 \mathrm{~mL} / \mathrm{min}$. The removal rate decreases with increasing flow rate. At the same time, the removal of pugian orange dye at different initial dye concentrations, stirring times, adsorbent dosages, and $\mathrm{pH}$ values using $\mathrm{RM}$ was studied [75-78]. When the initial $\mathrm{pH}$ is increased from 2.0 to 11.0, the removal rate decreases from 82 to 0 . The decrease in adsorption amount with $\mathrm{pH}$ value is due to the formation of a hydrate complex at the solid solution interface and subsequent acid-base dissociation. At $\mathrm{pH} 2.0$, the maximum removal rate of the dye is $82 \%$.

Ion exchange is the main mechanism of the adsorption process $[79,80]$. ARM was used to remove the Congo red dye in the batch adsorption experiment. In aqueous solutions, the $\mathrm{pH}$ value of the dye solution greatly influences the chemical properties of dye molecules and ARM. When adsorbing ARM, the effective $\mathrm{pH}$ is 7.0. The results show that the maximum monolayer adsorption capacity of ARM for Congo red is $7.08 \mathrm{mg} / \mathrm{g}$ within $90 \mathrm{~min}$. 
Methylene blue was removed by using fly ash and RM as adsorbent. Heat (overnight at $800{ }^{\circ} \mathrm{C}$ ) and chemical treatment of nitric acid solution were applied to the fly ash and RM samples $[81,82]$. The adsorption capacity of fly ash and RM is decreased by heating, but the adsorption of fly ash and $\mathrm{RM}$ treated by $\mathrm{HNO}_{3}$ is different. Nitric acid treatment improves the adsorption capacity of fly ash and decreases the adsorption capacity of RM. This condition indicates that some organic matter and hydroxyl groups decompose as the temperature increases, thereby decreasing the adsorption capacity. In addition, acid treatment promotes the dissolution of the mineral in carbon, thus increasing the pore volume of the fly ash sample and the adsorption capacity. However, for RM, acid treatment neutralizes hydroxyl ions on the alkaline surface, which is conducive to the adsorption of basic dyes.

A summary of the adsorption capacity of RM for different dyes is presented in Table 5. Evidently, RM exhibits inefficiency for dye removal. Therefore, further research on the removal of different classes of dyes using RM is necessary. Moreover, a substantial understanding of the mechanism of dye adsorption on RM is needed.

Table 5. Adsorption capacity of RM for the removal of different dyes from water [37,83-86]. Reproduced with permission from [37], published by Taylor \& Francis, 2011.

\begin{tabular}{cccc}
\hline Adsorbent & Adsorbate & Amount Adsorbed & Reference \\
\hline RM & Rhodamine B & $(1.01-1.16) \times 10^{-5} \mathrm{~mol} / \mathrm{g}$ & {$[83]$} \\
RM & Fast Green & $(7.25-9.35) \times 10^{-6} \mathrm{~mol} / \mathrm{g}$ & {$[83]$} \\
RM & Methylene blue & $(4.35-5.23) \times 10^{-5} \mathrm{~mol} / \mathrm{g}$ & {$[83]$} \\
RM & Congo red & $5.81 \times 10^{-6} \mathrm{~mol} / \mathrm{g}$ & {$[84]$} \\
RM & Acid violet & $2.42 \times 10^{-6} \mathrm{~mol} / \mathrm{g}$ & {$[85]$} \\
Acid-ARM & Congo red & $1.02 \times 10^{-5} \mathrm{~mol} / \mathrm{g}$ & {$[86]$} \\
\hline
\end{tabular}

\section{Treatment of Waste Gas}

The production of considerable $\mathrm{NO}_{x}, \mathrm{SO}_{x}$, and $\mathrm{H}_{2} \mathrm{~S}$ in various industries leads to serious air pollution. The alkaline substance in RM is abundant, which can purify and adsorb these gases. However, few studies are available on the use of RM in gas purification compared with other applications.

\subsection{Desulfurization Process}

RM can be divided into dry and wet methods for flue gas desulfurization [87]. The phase of RM is conducive to the flue gas desulfurization. The Gibbs free energy of the effective desulfurization component in RM is obtained through thermodynamic analysis of RM desulfurization at room temperature, and the reaction of sulfur dioxide is less than zero. Formulas (6)-(10) show that RM can be used in flue gas desulfurization, where $\mathrm{r}=$ reaction, $\mathrm{m}=\mathrm{mol}$.

$$
\begin{array}{cc}
\mathrm{Na}_{2} \mathrm{O}+\mathrm{SO}_{2} \rightarrow \mathrm{Na}_{2} \mathrm{SO}_{3} & \Delta \mathrm{rGm}(298 \mathrm{~K})=-333.138 \mathrm{~kJ} / \mathrm{mol} \\
4 \mathrm{Na}_{2} \mathrm{O}+4 \mathrm{SO}_{2} \rightarrow 3 \mathrm{Na}_{2} \mathrm{SO}_{4}+\mathrm{Na}_{2} \mathrm{~S} & \Delta \mathrm{rGm}(298 \mathrm{~K})=-1447.343 \mathrm{~kJ} / \mathrm{mol} \\
4 \mathrm{CaO}+4 \mathrm{SO}_{2} \rightarrow 3 \mathrm{CaSO}_{4}+\mathrm{CaS} & \Delta \mathrm{rGm}(298 \mathrm{~K})=-818.796 \mathrm{~kJ} / \mathrm{mol} \\
\mathrm{Al}_{2} \mathrm{O}_{3}+4.5 \mathrm{SO}_{2} \rightarrow \mathrm{Al}_{2}\left(\mathrm{SO}_{4}\right)_{3}+1.5 \mathrm{~S} & \Delta \mathrm{rGm}(298 \mathrm{~K})=-166.869 \mathrm{~kJ} / \mathrm{mol} \\
2 \mathrm{Fe}_{2} \mathrm{O}_{3}+5 \mathrm{SO}_{2} \rightarrow 4 \mathrm{FeSO}_{4}+\mathrm{S} & \Delta \mathrm{rGm}(298 \mathrm{~K})=-314.49 \mathrm{~kJ} / \mathrm{mol}
\end{array}
$$

\subsubsection{Dry Desulfurization}

The dry method for flue gas desulfurization uses some components to adsorb pollutants in RM.

$\mathrm{RM}$ is used for sulfur dioxide absorption and purification. Scientists found that $1 \mathrm{~kg}$ of RM can absorb $11.3 \mathrm{~g} \mathrm{SO}_{2}$ at dry desulfurization and that its desulfurization rate is approximately $50 \%$. In wet desulfurization, the $\mathrm{SO}_{2}$ adsorbed by the same $\mathrm{RM}$ is $16.3 \mathrm{~g}$, and the desulfurization rate is approximately $90 \%$ [88]. 
In China, Liu et al. used RM adsorption fluid to absorb and purify $\mathrm{SO}_{2}$ flue gas, and the $\mathrm{SO}_{2}$ absorption efficiency is higher than $98 \%$ [89]. Zhou et al. used Bayer $\mathrm{RM}$ to absorb $\mathrm{SO}_{2}$ in a bubbling reactor [90]. Results show that $\mathrm{RM}$ can effectively absorb $\mathrm{SO}_{2}$ at a highly close liquid/gas ratio. Therefore, RM can be used to desulfurize industrial waste gas and decrease environmental pollution. Ghosh et al. used RM to synthesize a compound RM desulfurizer with extremely high desulfurization activity through experimental studies [91]. The amount of RM is greater than $70 \%$, the desulfurization efficiency is over $90 \%$, and the sulfur capacity is over $15 \%$. The pore size of the RM desulfurizer is within the range of $0.94-4.3 \mathrm{~nm}$, and the effect of micro-pore desulfurization is the best. The more pores in the pore size range, the larger the sulfur capacity of the RM desulfurizer. The micropores on the surface of the desulfurizer particles are evenly distributed, and these pores can effectively transport $\mathrm{SO}_{2}$ to the interior of the particles, thereby providing a sufficient reaction surface and creating favorable conditions for optimal matching of diffusion and chemical reaction.

\subsubsection{Wet Desulfurization}

RM was used in the wet process for flue gas desulfurization, and its adsorption fluid reacts with acid gas. RM contains considerable alkaline substances, such as $\mathrm{Al}(\mathrm{OH})_{3}$ and $\mathrm{CaCO}_{3}$, which can react with an acidic gas. Most particles are amorphous and agglomerative, which form an agglomerative space. Therefore, RM has considerable pores, large specific surface area, and excellent adsorption capacity. In the RM adsorption of sulfuric acid fog, acid-base neutralization, surface adsorption, and pore filling may also play notable roles.

The use of sintering RM and activated carbon as raw materials to prepare ARM desulfurizer (ARMD) by thermal activation was studied to improve the desulfurization effect [92]. In the preparation process of ARMD, the effects of the ratio of activated carbon and $R M(C / R)$, temperature, and activation time on the desulfurization efficiency were investigated. In the test, the authors used a $300 \mathrm{~mm} \times$ $80 \mathrm{~mm}$ plexiglass bubbling absorber with an effective height of $200 \mathrm{~mm}$. The structure of the test device is shown in Figure 5. The experimental gas and desulfurization slurry were prepared by $\mathrm{SO}_{2}$ standard gas and air and ARMD and deionized water in proportion, respectively. The test gas was injected into the buffer bottle by the $\mathrm{SO}_{2}$ gas tank and air pump with a constant flow and then evenly mixed. The mixed gas enters the bubbling absorption at the bottom of the tower and reacts with the desulfurization slurry, which is then discharged after being absorbed by the exhaust gas absorption device. The results show that the best preparation conditions of ARMD are as follows: $C / R=1: 20$, $900{ }^{\circ} \mathrm{C}$ thermal activation temperature, and $15 \mathrm{~min}$ thermal activation time. When the $\mathrm{pH}$ value is 4.5 , RM desulfurization efficiency can reach $86.9 \%$.

Leal et al. studied the adsorption effect of RM on sulfuric acid fog by using fixed-bed dynamic adsorption [93]. The removal rate of RM on sulfuric acid fog is high (more than 95\%) [92,93]. Qu et al. conducted desulfurization experiments by using sintered RM slurry [94]. XRD analysis results of RM desulfurization reaction before and after the experiments showed that the portlandite, calcite, and hydrated garnet phases completely disappear, but considerable calcium sulfite, gypsum, and other new phases appear. This result indicates that during the chemical reactivity, the reaction compositions of the solid phase in the desulfurization reaction are mainly $\mathrm{Na}_{2} \mathrm{O}, \mathrm{CaO}$, and $\mathrm{Al}_{2} \mathrm{O}_{3}$. The reaction ends when the residual $\mathrm{Na}_{2} \mathrm{O}$ mass fraction is decreased to less than $1 \%$.

Buda et al. studied the flue gas desulfurization of RM $[95,96]$. The authors conducted an orthogonal experimental study on the liquid-solid and gas-liquid ratios, gas flow rate, and gas temperature influence on the desulfurization efficiency. The results show the influence of various factors on the desulfurization efficiency of size for primary and secondary gas-liquid ratio $>$ solid-liquid ratio $>$ flue gas temperature, and the excellent process conditions are 7:1 liquid-solid ratio, $3.6 \mathrm{~m}^{3} / \mathrm{h}$ flue gas rate, 15:1 natural gas liquid proportion, and $20^{\circ} \mathrm{C}$ flue gas temperature. The research results and device design provide theoretical basis and technical support for the industrialization promotion of RM flue gas desulfurization. 


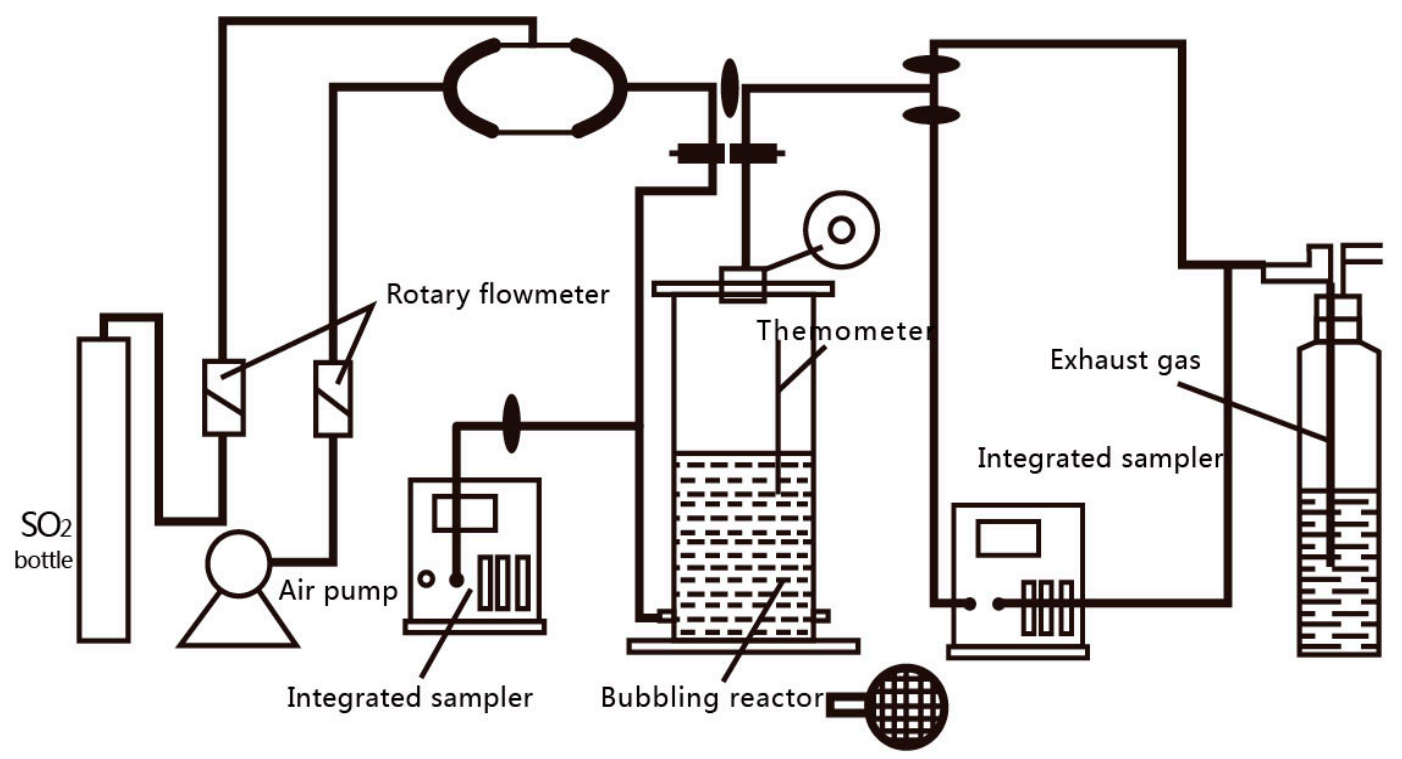

Figure 5. Structure of the test device.

Fois et al. conducted an engineering test on Bayer RM desulfurization by using an absorption system composed of supply, $\mathrm{SO}_{2}$ absorption, flue gas, and auxiliary treatment schemes [97]. Red slurry, an absorbent, was mixed with flue gas in the absorption tower. The $\mathrm{SO}_{2}$ in flue gas was chemically reacted with red slurry, and air was pumped into it. The final reaction product is RM containing sulfate to fix sulfur using RM. A patent of "a way to use RM disposal method of flue gas and recycling metal iron, aluminum," was proposed by Lu [98]. First, flue gas was mixed with RM to complete the dealkalization of the RM separation of mud filtrate. Then, the flue gas was mixed with supernatant on RM filtrate, which is obtained by $\mathrm{pH}$ control. Thus, iron and aluminum hydroxide should precipitate to realize the separation of iron and aluminum and obtain their recovery rates of $70 \%$ and $72 \%$ or higher, respectively.

\subsection{Decarburizing Process}

Alharthi et al. used original and neutral RM to absorb $\mathrm{CO}_{2}$ [99]. After carbonization, the total alkalinity of the aforementioned RM is decreased by $85 \%$ and $89 \%$. The authors also used the activated $\mathrm{RM}$ after $\mathrm{CO}_{2}$ carbide to perform zinc (II) adsorption experiment. The results exhibit a zinc absorption (II) capacity of $14.92 \mathrm{mg} / \mathrm{g}$ after high temperature roasting activation. Wang et al. used Bayer RM to capture $\mathrm{CO}_{2}$ [100]. Under the best experimental conditions, the alkali removal rate of RM is up to $42 \%$ [101]. The aim of waste gas treatment can be achieved by using RM from solid waste to absorb $\mathrm{CO}_{2}$ from industrial waste gas. Babuponnusami et al. studied the solidification and storage capacity of $\mathrm{RM}$ for $\mathrm{CO}_{2}$ under different pressures and the chemical transformation behavior of mineral phases during $\mathrm{CO}_{2}$ solidification [100,101]. The mineral phases formed after $\mathrm{RM}$ solidified $\mathrm{CO}_{2}$ are mainly calcium nephrite and calcite $\left(\mathrm{CaCO}_{3}\right)$. Thus, $\mathrm{RM}$ exhibits an excellent effect as $\mathrm{CO}_{2}$ curing agent.

Chaerun et al. [102] utilized RM as an alkaline absorbent for the treatment of sewage sludge in a green supercritical water oxidation system. They concluded that the green disposal method significantly reduces the $\mathrm{CO}_{2}, \mathrm{SO}_{2}$, and nitrogen oxide levels in the supercritical water oxidation disposal by 800,15 , and $12 \mathrm{ppm}$, respectively. The process to treat sewage sludge using RM is shown in Figure 6. 


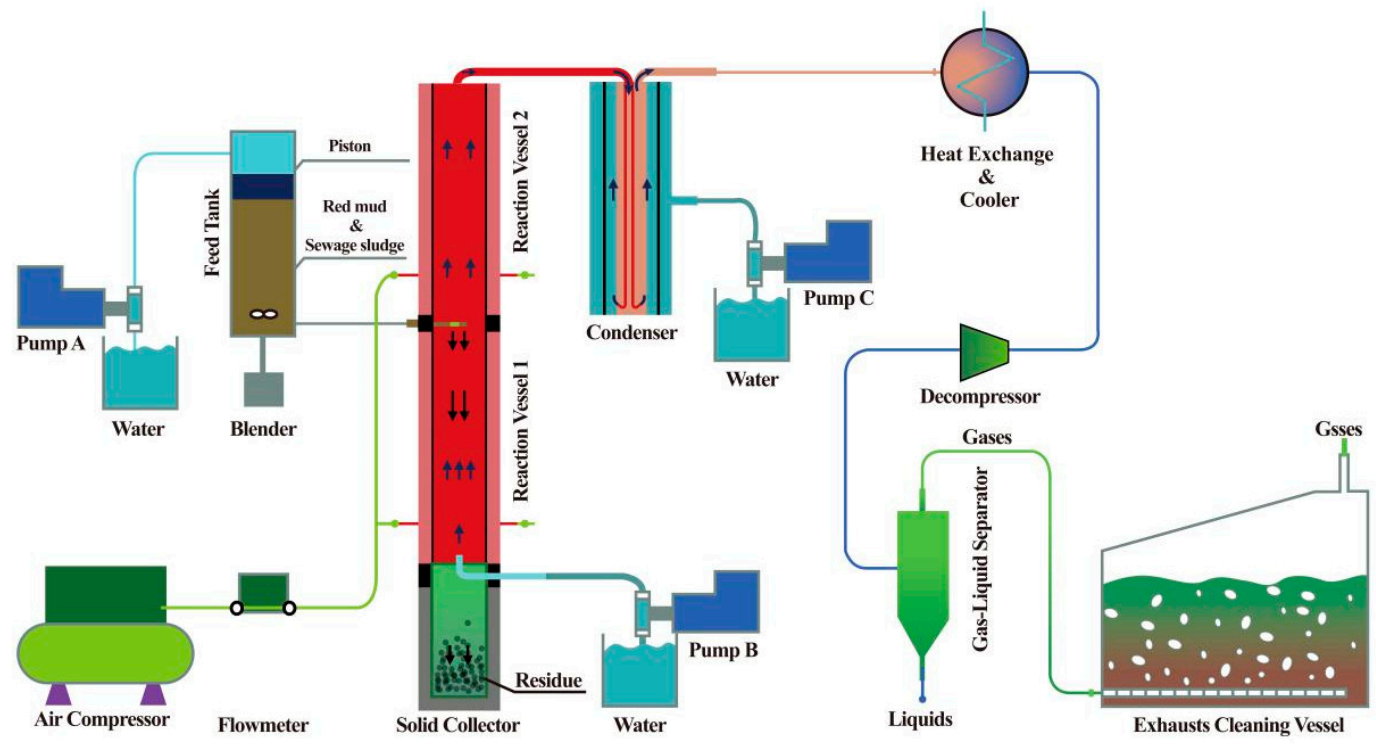

Figure 6. Supercritical water oxidation system for sewage sludge treatment using red mud. Reproduced with permission from [81], published by Elsevier Ltd., 2016.

\section{Remediation of Heavy Metal Contaminated Soils}

At present, the deterioration of regional agricultural environment and heavy metal pollution of agricultural products is highly serious, especially in developed areas. Statistics show that Cd, As, $\mathrm{Pb}, \mathrm{Cr}, \mathrm{Hg}$, and other heavy metals contaminate farmland approximately 20 million $\mathrm{hm}^{2}$, thereby accounting for approximately $1 / 5$ of the total arable land [103]. Therefore, passivation removal of heavy metals in soil is of great importance.

Many studies using RM to remediate metal-contaminated soils have shown that decreasing metal concentrations in plants directly or indirectly consumed by human beings through food crops is beneficial to human health [104]. The metal concentration of plants in potted and field compared with those grown in unrepaired soil decreases by more than $50 \%$.

$\mathrm{RM}$ can effectively decrease the amounts of $\mathrm{Cd}, \mathrm{Pb}$, and $\mathrm{Zn}$ in plants grown in metal/metalloid contaminated soils. The metal concentration in plant tissues (rice grains) decreases from $0.25 \%$ to $1.25 \%$ with increasing RM application [105]. According to the comparison result of the contents of $\mathrm{Cd}, \mathrm{Pb}$, and $\mathrm{Zn}$ in pea (Pisum sativum L.) and wheat (Triticum vulgare L.), the metal content in plants grown with RM is considerably decreased [106]. Also, the addition of RM increases the proportion of metal accumulation in the roots compared with the buds of the two plants. The translocation factors (TFs, metal concentration in shoot/root) for $\mathrm{Cd}, \mathrm{Pb}$, and $\mathrm{Zn}$ in peas grown in $\mathrm{RM}$-amended soil are 0.086 , 0.028 , and 0.279 , respectively, which are considerably lower than those in peas grown in unamended soil $(0.384,0.052$, and 0.825 , respectively). Similar changes in metal TFs after RM modification were also reported in wheat plants.

RM considerably decreases the absorption and accumulation of As in the ground and root of maize. Moreover, RM and compost can fix $\mathrm{Zn}$ in soil and decrease the element's plant effectiveness. $\mathrm{RM}$ and compost were applied to contaminated soils, and the effect of $\mathrm{Zn}$ on fixed soils is better than that of separately adding compost.

The effects of RM and sludge on the chemical morphology of $\mathrm{Zn}$ in soils were studied by Huang et al. [107]. Results showed that the use of RM alone can effectively decrease Zn content in the soil, and the effect of using RM or sludge to stabilize $\mathrm{Zn}$ is better than that of RM and sludge, which cannot only promote the effective state $\mathrm{Zn}$ conversion to the non-available $\mathrm{Zn}$ but also increase soil fertility. Huang et al. studied the effects of applying RM and lime on maize uptake and accumulation of Cd [108] and found that RM and lime considerably improve the soil $\mathrm{pH}$ value and decrease the $\mathrm{Cd}$ content in the soil and the absorption and accumulation of $\mathrm{Cd}$. The effects of soil RM and pig manure matching on 
the rice antioxidant enzyme system and $\mathrm{Cd}$ uptake in paddy soils were studied by field experiments. Results showed that rice yield increases in a certain amount of RM/pig manure.

$\mathrm{RM}$ can also decrease metal production in vegetables [109]. The concentrations of $\mathrm{As}, \mathrm{Cd}, \mathrm{Pb}$, and $\mathrm{Zn}$ in lettuce (Lactuca sativa L.) grown in soil decrease by $32.8 \%, 83.5 \%, 35.4 \%$, and $81.0 \%$, respectively, compared with unamended soil. The effects of sludge and RM on soil physicochemical properties, rape growth, quality, and nutrient status were studied in systems. Data showed that the application of sludge and RM can improve the growth status, yield, and absorption of nitrogen, phosphorus, and potassium and the nutritional status of rapeseed [110]. Improving soil properties is advantageous for the improvement of soil organic matter, nitrogen, and phosphorus nutrient contents to regulate soil $\mathrm{pH}$ and conductivity.

The use of RM has another positive effect on contaminated soils [111]. This approach could decrease the vast volumes of RM in storage. Therefore, using RM as a soil amendment is an effective way to decrease RM storage. In summary, a decision tree scheme was proposed to evaluate the applicability of RM as an adsorbent for the treatment of contaminated soil (Figure 7).

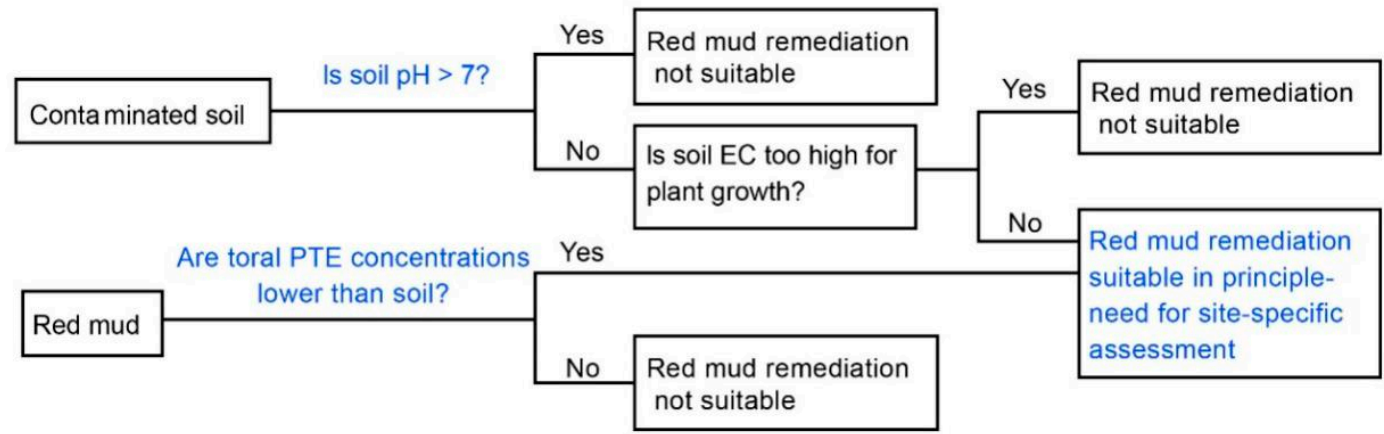

Figure 7. Proposed scheme for assessing the use of RM to treat the contaminated soil. Reproduced with permission from [5], published by Elsevier B.V., 2016.

Although RM has made considerable progress in repairing heavy metal soils, consideration of its use in food or forage crops could bring contamination into the human food chain, and further research is needed. Amendments could be used to grow plants that are unsuitable for human consumption in contaminated soil, and RM improvement of contaminated soil would have broader benefits for ecological restoration.

\section{Conclusions}

RM is widely used as an adsorbent in the effective removal of heavy metal and non-metal ions, organic pollutants, and dyes in wastewater treatment as well as sulfides and carbides in waste gas treatment, in the adsorption of pollutants in soil, and in the restoration of contaminated soil. This approach achieved excellent results. However, direct use of raw RM as an adsorbent has limited adsorption capacity. Pretreatment methods, such as acid activation, alkali activation, and heat treatment, are mainly adopted to improve its adsorption capacity. In the future, the manner of finding cheap and efficient modification methods is an important research direction. Moreover, the mechanism by which RM treats various pollutants in water as an adsorption material needs to be elucidated. RM contains rich valuable metals and active ingredients, such as iron, aluminum, and silicon. Maximizing these characteristics to prepare new high-efficiency adsorbents and improve the added value of products is also an important research topic. Main problems existing in the comprehensive utilization of RM are as follows:

1. Methods of recycling or disposal after adsorption of heavy metals to prevent secondary pollution.

2. Study of adsorbents that are more conducive to storage and transportation.

3. Further improvement of adsorption performance (such as making porous nanostructures). 
4. Strategies to avoid secondary pollution of RM (leaching of heavy metals) in adsorption.

Author Contributions: Conceptualization, W.S. and H.T.; methodology, L.W.; software, G.H.; validation, L.W., R.L. and F.L.; formal analysis, H.H.; investigation, Y.Y.; resources, H.H.; data curation, Y.Y. and T.Y.; writing-original draft preparation, F.L.; writing—review and editing, G.H.; visualization, L.W.; supervision, H.T. and T.Y.; project administration, W.S; funding acquisition, H.T.

Funding: This research was funded by National Key Scientific Research Project (2018YFC1901901); the Natural Science Foundation of China (NSFC, 51704329); the project of Sublimation Scholar's Distinguished Professor of Central South University; the National 111 Project (No. B14034); Collaborative Innovation Center for Clean and Efficient Utilization of Strategic Metal Mineral Resources; Key Laboratory of Hunan Province for Clean and Efficient Utilization of Strategic Calcium-containing Mineral Resources (No. 2018TP1002); Open Foundation of State Key Laboratory of Mineral Processing (BGRIMM-KJSKL-2019-18).

Conflicts of Interest: The authors declare no conflict of interest. The funders had no role in the design of the study; in the collection, analyses, or interpretation of data; in the writing of the manuscript; or in the decision to publish the result.

\section{References}

1. Wang, X.; Zhang, Y.; Liu, J.; Hu, P.; Meng, K.; Lv, F.; Tong, W.; Chu, P.K. Dealkalization of red mud by carbide slag and flue gas. CLEAN Soil Air Water 2017, 46, 1700634. [CrossRef]

2. Lyu, F.; Sun, N.; Sun, W.; Khoso, S.A.; Tang, H.-H.; Wang, L. Preliminary assessment of revegetation potential through ryegrass growing on bauxite residue. J. Cent. South Univ. 2019, 26, 404-409. [CrossRef]

3. Guo, Y.; Zhao, Q.; Yan, K.; Cheng, F.; Lou, H. Novel Process for Alumina Extraction via the Coupling Treatment of Coal Gangue and Bauxite Red Mud. Ind. Eng. Chem. Res. 2014, 53, 4518-4521. [CrossRef]

4. Lyu, F.; Gao, J.-D.; Sun, W.; Liu, R.-Q.; Sun, X.-D.; Cao, X.-F.; Wang, L.; Sun, W. Utilisation of propyl gallate as a novel selective collector for diaspore flotation. Miner. Eng. 2019, 131, 66-72. [CrossRef]

5. Hua, Y.; Heal, K.V.; Friesl-Hanl, W. The use of red mud as an immobiliser for metal/metalloid-contaminated soil: A review. J. Hazard. Mater. 2016, 325, 17. [CrossRef]

6. Oliveira, A.A.S.; Tristão, J.C.; Ardisson, J.D.; Dias, A.; Lago, R.M. Production of nanostructured magnetic composites based on $\mathrm{Fe}^{0}$ nuclei coated with carbon nanofibers and nanotubes from red mud waste and ethanol. Appl. Catal. B Environ. 2011, 105, 163-170. [CrossRef]

7. Kinnarinen, T.; Huhtanen, M.; Holliday, L.; Häkkinen, A. Challenges related to solute analysis of bauxite residue filter cakes. Miner. Eng. 2018, 120,1-6. [CrossRef]

8. Liu, S.; Rehren, T.; Chen, J.; Xu, C.; Venunan, P.; Larreina-Garcia, D.; Martinón-Torres, M. Bullion production in imperial china and its significance for sulphide ore smelting world-wide. J. Archaeol. Sci. 2015, 55, 151-165. [CrossRef]

9. $\quad \mathrm{Fu}$, J.; Song, R.; Mao, W.J.; Wang, Q.; An, S.Q.; Zeng, Q.F.; Zhu, H.L. Adsorption of disperse blue 2BLN by microwave activated red mud. Environ. Prog. Sustain. Energy 2011, 30, 558-566. [CrossRef]

10. Boubakri, A.; Hafiane, A.; Bouguecha, S.A.T. Direct contact membrane distillation: Capability to desalt raw water. Arab. J. Chem. 2017, 10, S3475-S3481. [CrossRef]

11. Mehdilo, A.; Zarei, H.; Irannajad, M.; Arjmandfar, H.J.M.E. Flotation of zinc oxide ores by cationic and mixed collectors. Miner. Eng. 2012, 36-38, 331-334. [CrossRef]

12. Çoruh, S.; Ergun, O.N. Use of fly ash, phosphogypsum and red mud as a liner material for the disposal of hazardous zinc leach residue waste. J. Hazard. Mater. 2010, 173, 468-473. [CrossRef]

13. Rafiq, Z.; Nazir, R.; Shahwar, D.-e.; Shah, M.R.; Ali, S. Utilization of magnesium and zinc oxide nanoadsorbents as potential materials for treatment of copper electroplating industry wastewater. J. Environ. Chem. Eng. 2014, 2, 642-651. [CrossRef]

14. András, G. The red mud accident in Ajka (Hungary): Characterization and potential health effects of fugitive dust. Environ. Sci. Technol. 2011, 4, 1608-1615.

15. Kushwaha, S.S.; Kishan, D.; Chauhan, M.S.; Khetawath, S. Stabilization of red mud using eko soil enzyme for highway embankment. Mater. Today Proc. 2018, 5, 20500-20512. [CrossRef]

16. Lee, S.-H.; Kumar, R.; Jeon, B.-H. Struvite precipitation under changing ionic conditions in synthetic wastewater: Experiment and modeling. J. Colloid Interface Sci. 2016, 474, 93-102. [CrossRef] 
17. Sahu, M.K.; Mandal, S.; Yadav, L.S.; Dash, S.S.; Patel, R.K. Equilibrium and kinetic studies of Cd(II) ion adsorption from aqueous solution by activated red mud. Desalin. Water Treat. 2016, 57, 14251-14265. [CrossRef]

18. Narayanan, R.P.; Ma, L.-C.; Kazantzis, N.K.; Emmert, M.H. Cost analysis as a tool for the development of Sc recovery processes from bauxite residue (red mud). ACS Sustain. Chem. Eng. 2018, 6, 5333-5341. [CrossRef]

19. Wu, C.-S.; Liu, D.-Y. Mineral phase and physical properties of red mud calcined at different temperatures. J. Nanomater. 2012, 2012, 2. [CrossRef]

20. Zhu, D.; Zhou, X.; Pan, J.; Luo, Y. Direct reduction and beneficiation of a refractory siderite lump. Miner. Process. Extr. Metall. 2014, 123, 246-250. [CrossRef]

21. Deilami-nezhad, L.; Moghaddam-Banaem, L.; Sadeghi, M. Development of bone seeker radiopharmaceuticals by scandium-47 and estimation of human absorbed dose. Appl. Radiat. Isot. 2017, 129, 108-116. [CrossRef] [PubMed]

22. Rees, E.E.; Petukhova, T.; Mascarenhas, M.; Pelcat, Y.; Ogden, N.H. Environmental and social determinants of population vulnerability to zika virus emergence at the local scale. Parasites Vectors 2018, 11, 290. [CrossRef]

23. Ascensão, G.; Seabra, M.P.; Aguiar, J.B.; Labrincha, J.A. Red mud-based geopolymers with tailored alkali diffusion properties and ph buffering ability. J. Clean. Prod. 2017, 148, 23-30. [CrossRef]

24. Novais, R.M.; Carvalheiras, J.; Seabra, M.P.; Pullar, R.C.; Labrincha, J.A. Innovative application for bauxite residue: Red mud-based inorganic polymer spheres as pH regulators. J. Hazard. Mater. 2018, 358, 69-81. [CrossRef]

25. Zheng, P.; Zhang, K.; Dang, Y.; Bai, B.; Guan, W.; Suo, Y. Adsorption of organic dyes by $\mathrm{TiO}_{2} @ y e a s t-c a r b o n$ composite microspheres and their in situ regeneration evaluation. J. Nanomater. 2015, 3, 6.

26. Reddy, N.G.; Rao, B.H. Characterization of settled particles of the red mud waste exposed to different aqueous environmental conditions. Indian Geotech. J. 2018, 48, 1-15.

27. Liang, G.; Chen, W.; Nguyen, A.V.; Nguyen, T.A.H. Red mud carbonation using carbon dioxide: Effects of carbonate and calcium ions on goethite surface properties and settling. J. Colloid Interface Sci. 2018, 517, 230-238. [CrossRef]

28. Christoforakos, N.P.R.; Lazaridis, N.K. Melanoidin removal from aqueous systems by a hybrid flotationfiltration technique. J. Chem. Technol. Biotechnol. 2018, 93, 2422-2428. [CrossRef]

29. Arbabi, M.; Golshani, N. Removal of copper ions Cu (II) from industrial wastewater: A review of removal methods. Int. J. Epidemiol. Res. 2016, 3, 283-293.

30. Taheri, M.; Alavi Moghaddam, M.R.; Arami, M. Techno-economical optimization of reactive blue 19 removal by combined electrocoagulation/coagulation process through Mopso using RSM and Anfis models. J. Environ. Manag. 2013, 128, 798-806. [CrossRef]

31. Golder, A.K.; Samanta, A.N.; Ray, S. Anionic reactive dye removal from aqueous solution using a new adsorbent-Sludge generated in removal of heavy metal by electrocoagulation. Chem. Eng. J. 2006, 122, 107-115. [CrossRef]

32. Barakat, M.A. New trends in removing heavy metals from industrial wastewater. Arab. J. Chem. 2011, 4, 361-377. [CrossRef]

33. Boukli-Hacene, N. Weighted pseudo-almost automorphic solutions for some partial functional differential equations. Nonlinear Anal. Real World Appl. 2011, 12, 562-570. [CrossRef]

34. Górka, A.; Zamorska, J.; Antos, D. Coupling Ion Exchange and Biosorption for Copper(II) Removal From Wastewaters. Ind. Eng. Chem. Res. 2011, 50, 3494-3502. [CrossRef]

35. Barron, O.E.; Qu, H.J.A.R. Information Asymmetry and the Ex Ante Impact of Public Disclosure Quality on Price Efficiency and the Cost of Capital: Evidence from a Laboratory Market. Account. Rev. 2014, 89, 1269-1297. [CrossRef]

36. Yan, Z.G.; Meng, W.; Liu, Z.T.; Feng-Chang, W.U.; Wang, H.; Zhou, J.L.; Yang, N.Y.; Zhang, Y.H. Development of aquatic life criteria and lash-up standard for ammonia in liao river basin. China Environ. Sci. 2011, 31, 1829-1835.

37. Bhatnagar, A.; Vilar, V.J.P.; Botelho, C.M.S.; Boaventura, R.A.R. A review of the use of red mud as adsorbent for the removal of toxic pollutants from water and wastewater. Environ. Technol. 2011, 32, 231-249. [CrossRef]

38. Tsamo, C.; Djomou Djonga, P.N.; Dangwang Dikdim, J.M.; Kamga, R. Kinetic and equilibrium studies of $\mathrm{Cr}(\mathrm{VI}), \mathrm{Cu}(\mathrm{II})$ and $\mathrm{Pb}(\mathrm{II})$ removal from aqueous solution using red mud, a low-cost adsorbent. Arab. J. Sci. Eng. 2018, 43, 2353-2368. [CrossRef] 
39. Kim, S.C.; Nahm, S.W.; Park, Y.-K. Property and performance of red mud-based catalysts for the complete oxidation of volatile organic compounds. J. Hazard. Mater. 2015, 300, 104-113. [CrossRef] [PubMed]

40. Li, C.; Yu, J.; Li, W.; He, Y.; Qiu, Y.; Li, P.; Wang, C.; Huang, F.; Wang, D.; Gao, S. Immobilization, enrichment and recycling of $\mathrm{Cr}(\mathrm{VI})$ from wastewater using a red mud/carbon material to produce the valuable chromite $\left(\mathrm{FeCr}_{2} \mathrm{O}_{4}\right)$. Chem. Eng. J. 2018, 350, 1103-1113. [CrossRef]

41. Sahu, R.C.; Patel, R.; Ray, B.C. Removal of hydrogen sulfide using red mud at ambient conditions. Fuel Process. Technol. 2011, 92, 1587-1592. [CrossRef]

42. Cao, J.-L.; Yan, Z.-L.; Deng, Q.-F.; Wang, Y.; Yuan, Z.-Y.; Sun, G.; Jia, T.-K.; Wang, X.-D.; Bala, H.; Zhang, Z.-Y. Mesoporous modified-red-mud supported Ni catalysts for ammonia decomposition to hydrogen. Int. J. Hydrog. Energy 2014, 39, 5747-5755. [CrossRef]

43. Oliveira, A.A.S.; Costa, D.A.S.; Teixeira, I.F.; Moura, F.C.C. Gold nanoparticles supported on modified red mud for biphasic oxidation of sulfur compounds: A synergistic effect. Appl. Catal. B Environ. 2015, 162, 475-482. [CrossRef]

44. Grujicic, M.; Yavari, R.; Snipes, J.; Ramaswami, S. A linear friction welding process model for Carpenter Custom 465 precipitation-hardened martensitic stainless steel: A weld microstructure-evolution analysis. Proc. Inst. Mech. Eng. Part B: J. Eng. Manuf. 2015, 229. [CrossRef]

45. Chen, X.; Xiang, H.; Hu, Y.; Zhang, Y.; Ouyang, L.; Gao, M. Fates of microcystis aeruginosa cells and associated microcystins in sediment and the effect of coagulation process on them. Toxins 2013, 6, 152-167. [CrossRef]

46. Yu, L. Biodegradation of decabromodiphenyl ether (BDE-209) by crude enzyme extract from pseudomonas aeruginosa. Int. J. Environ. Res. Public Health 2015, 9, 11829-11847.

47. Chiang, Y.W.; Ghyselbrecht, K.; Santos, R.M.; Martens, J.A.; Swennen, R.; Cappuyns, V.; Meesschaert, B. Adsorption of multi-heavy metals onto water treatment residuals: Sorption capacities and applications. Chem. Eng. J. 2012, 200-202, 405-415. [CrossRef]

48. Zhao, Y.; Wendling, L.A.; Wang, C.; Pei, Y. Use of Fe/Al drinking water treatment residuals as amendments for enhancing the retention capacity of glyphosate in agricultural soils. J. Environ. Sci. 2015, 34, 133-142. [CrossRef] [PubMed]

49. Bai, J.; Xiao, R.; Zhang, K.; Gao, H. Arsenic and heavy metal pollution in wetland soils from tidal freshwater and salt marshes before and after the flow-sediment regulation regime in the yellow river delta, China. J. Hydrol. 2012, 450-451, 244-253. [CrossRef]

50. Bai, J.; Xiao, R.; Cui, B.; Zhang, K.; Wang, Q.; Liu, X.; Gao, H.; Huang, L. Assessment of heavy metal pollution in wetland soils from the young and old reclaimed regions in the pearl river estuary, South China. Environ. Pollut. 2011, 159, 817-824. [CrossRef] [PubMed]

51. Sudduth, E.; Perakis, S.; Bernhardt, E. Nitrate in watersheds: Straight from soils to streams? J. Geophys. Res. Biogeosci. 2014, 118, 291-302. [CrossRef]

52. Do Prado, N.T.; Heitmann, A.P.; Mansur, H.S.; Mansur, A.A.; Oliveira, L.C.A.; de Castro, C.S. Pet-modified red mud as catalysts for oxidative desulfurization reactions. J. Environ. Sci. 2017, 57, 312-320. [CrossRef]

53. Belviso, C.; Agostinelli, E.; Belviso, S.; Cavalcante, F.; Pascucci, S.; Peddis, D.; Varvaro, G.; Fiore, S. Synthesis of magnetic zeolite at low temperature using a waste material mixture: Fly ash and red mud. Microporous Mesoporous Mater. 2015, 202, 208-216. [CrossRef]

54. McNevin, A.A.; Boyd, C.E. Copper concentrations in channel catfish ictalurus punctatus ponds treated with copper sulfate. J. World Aquacult. Soc. 2007, 35, 16-24. [CrossRef]

55. Yu, Y.; Paul Chen, J. Key factors for optimum performance in phosphate removal from contaminated water by a Fe-Mg-La tri-metal composite sorbent. J. Colloid Interface Sci. 2015, 445, 303-311. [CrossRef] [PubMed]

56. Mahani, H.; Levy Keya, A.; Berg, S.; Bartels, W.-B.; Nasralla, R.; Rossen, W.R. Insights into the mechanism of wettability alteration by low-salinity-flooding (LSF) in carbonates. Energy Fuels 2015, 29, 1352-1367. [CrossRef]

57. Kumar Yadav, K.; Gupta, N.; Kumar, A.; Reece, L.M.; Singh, N.; Rezania, S.; Ahmad Khan, S. Mechanistic understanding and holistic approach of phytoremediation: A review on application and future prospects. Ecol. Eng. 2018, 120, 274-298. [CrossRef]

58. Duan, F.; Chen, C.; Zhao, X.; Yang, Y.; Liu, X.; Qin, Y. Water-compatible surface molecularly imprinted polymers with synergy of bi-functional monomers for enhanced selective adsorption of bisphenol a from aqueous solution. Environ. Sci. Nano 2016, 3, 213-222. [CrossRef] 
59. Guo, L.-X.; Xu, X.-M.; Yuan, J.-P.; Wu, C.-F.; Wang, J.-H. Characterization and authentication of significant chinese edible oilseed oils by stable carbon isotope analysis. J. Am. Oil Chem. Soc. 2010, 87, 839-848. [CrossRef]

60. Wang, L.; Ji, B.; Hu, Y.; Liu, R.; Sun, W. A review on in situ phytoremediation of mine tailings. Chemosphere 2017, 184, 594-600. [CrossRef]

61. Ahmad, A.L.; Yusuf, N.M.; Ooi, B.S. Preparation and modification of poly (vinyl) alcohol membrane: Effect of crosslinking time towards its morphology. Desalination 2012, 287, 35-40. [CrossRef]

62. Liang, W.; Couperthwaite, S.J.; Kaur, G.; Yan, C.; Johnstone, D.W.; Millar, G.J. Effect of strong acids on red mud structural and fluoride adsorption properties. J. Colloid Interface Sci. 2014, 423, 158-165. [CrossRef]

63. Ju, S.H.; Lu, S.D.; Peng, J.H.; Zhang, L.B.; Srinivasakannan, C.; Guo, S.H.; Wei, L. Removal of cadmium from aqueous solutions using red mud granulated with cement. Trans. Nonferrous Met. Soc. China. 2012, 22, 3140-3146. [CrossRef]

64. Gupta, N.; Yadav, K.K.; Kumar, V.; Kumar, S.; Chadd, R.P.; Kumar, A. Trace elements in soil-vegetables interface: Translocation, bioaccumulation, toxicity and amelioration-A review. Sci. Total Environ. 2019, 651, 2927-2942. [CrossRef] [PubMed]

65. Li, C.; Zeng, H.; Liu, P.; Yu, J.; Guo, F.; Xu, G.; Zhang, Z.-G. The recycle of red mud as excellent SCR catalyst for removal of $\mathrm{NO}_{\mathrm{x}}$. RSC Adv. 2017, 7, 53622-53630. [CrossRef]

66. Liu, T.; Li, F.; Jin, Z.; Yang, Y. Acidic leaching of potentially toxic metals cadmium, cobalt, chromium, copper, nickel, lead, and zinc from two Zn smelting slag materials incubated in an acidic soil. Environ. Pollut. 2018, 238, 359-368. [CrossRef] [PubMed]

67. Panda, I.; Jain, S.; Das, S.K.; Jayabalan, R. Characterization of red mud as a structural fill and embankment material using bioremediation. Int. Biodeterior. Biodegrad. 2017, 119, 368-376. [CrossRef]

68. Yan, S.; Song, W. Photo-transformation of pharmaceutically active compounds in the aqueous environment: A review. Environ. Sci. Process. Impacts 2014, 16, 697-720. [CrossRef]

69. Smiljanić, S.; Smičiklas, I.; Perić-Grujić, A.; Lončar, B.; Mitrić, M. Rinsed and thermally treated red mud sorbents for aqueous $\mathrm{Ni}^{2+}$ ions. Chem. Eng. J. 2010, 162, 75-83. [CrossRef]

70. Li, Z.; Din, J.; Xu, J.; Liao, C.; Yin, F.; Lü, T.; Cheng, L.; Li, J. Discovery of the REE minerals in the Wulong-Nanchuan bauxite deposits, Chongqing, China: Insights on conditions of formation and processes. J. Geochem. Explor. 2013, 133, 88-102. [CrossRef]

71. Li, W.; Ning, S.; Zhen, W.; Haisheng, H.; Yue, Y.; Runqing, L.; Yuehua, H.; Honghu, T.; Wei, S. Self-assembly of mixed dodecylamine-dodecanol molecules at the air/water interface based on large-scale molecular dynamics. J. Mol. Liq. 2019, 276, 867-874.

72. Zhang, L.; Zhang, H.; Guo, W.; Tian, Y. Removal of malachite green and crystal violet cationic dyes from aqueous solution using activated sintering process red mud. Appl. Clay Sci. 2014, 93-94, 85-93. [CrossRef]

73. Ghosh, I.; Guha, S.; Balasubramaniam, R.; Kumar, A.V.R. Leaching of metals from fresh and sintered red mud. J. Hazard. Mater. 2011, 185, 662-668. [CrossRef]

74. Yordanova, G.; Godjevargova, T.; Nenkova, R.; Ivanova, D. Biodegradation of phenol and phenolic derivatives by a mixture of immobilized cells of aspergillus awamori and trichosporon cutaneum. Biotechnol. Biotechnol. Equip. 2013, 27, 3681-3688. [CrossRef]

75. Gupta, V.; Ali, P.I.; Saini, V. Removal of rhodamine b, fast green, and methylene blue from wastewater using red mud, an aluminum industry waste. Ind. Eng. Chem. Res. 2004, 43, 1740-1747. [CrossRef]

76. Abu-El-Halawa, R.; Zabin, S.A. Removal efficiency of $\mathrm{Pb}, \mathrm{Cd}, \mathrm{Cu}$ and $\mathrm{Zn}$ from polluted water using dithiocarbamate ligands. J. Taibah Univ. Sci. 2017, 11, 57-65. [CrossRef]

77. Tor, A.; Cengeloglu, Y.; Ersoz, M. Increasing the phenol adsorption capacity of neutralized red mud by application of acid activation procedure. Desalination 2009, 242, 19-28. [CrossRef]

78. Gupta, V.K.; Ali, I.; Saini, V.K. Removal of Chlorophenols from Wastewater Using Red Mud: An Aluminum Industry Waste. Environ. Sci. Technol. 2004, 38, 4012-4018. [CrossRef]

79. Tang, Z.X.; Chen, Y.; Xue, J.; Yue, S. Adsorption and removal of Congo red dye from aqueous solution by using nano-Fe $\mathrm{O}_{4}$. Adv. Mater. Res. 2012, 503-504, 262-265. [CrossRef]

80. Shenvi, S.S.; Isloor, A.M.; Ismail, A.F.; Shilton, S.J.; Ahmad, A.A. Humic acid based biopolymeric membrane for effective removal of methylene blue and rhodamine B. Ind. Eng. Chem. Res. 2015, 54, 4965-4975. [CrossRef] 
81. Qian, L.; Wang, S.; Xu, D.; Guo, Y.; Tang, X.; Wang, L. Treatment of municipal sewage sludge in supercritical water: A review. Water Res. 2016, 89, 118-131. [CrossRef]

82. Sahu, R.C.; Patel, R.; Ray, B.C. Utilization of activated $\mathrm{CO}_{2}$-neutralized red mud for removal of arsenate from aqueous solutions. J. Hazard. Mater. 2010, 179, 1007-1013. [CrossRef] [PubMed]

83. Liu, Q.; Zhou, Y.; Zou, L.; Deng, T.; Zhang, J.; Sun, Y.; Ruan, X.; Zhu, P.; Qian, G. Simultaneous wastewater decoloration and fly ash dechlorination during the dye wastewater treatment by municipal solid waste incineration fly ash. Desalin. Water Treat. 2011, 32, 179-186. [CrossRef]

84. Samanta, A.; Das, S.; Jana, S. Exploring $\beta$-Feooh nanorods as an efficient adsorbent for arsenic and organic dyes. Chem. Sel. 2018, 3, 2467-2473. [CrossRef]

85. Namasivayam, C.; Arasi, D.J.S.E. Removal of Congo red from wastewater by adsorption onto waste red mud. Chemosphere 1997, 34, 401-417. [CrossRef]

86. Namasivayam, C.; Yamuna, R.; Arasi, D. Removal of acid violet from wastewater by adsorption on waste red mud. Environ. Geol. 2001, 41, 269-273.

87. Tor, A.; Cengeloglu, Y. Removal of Congo red from aqueous solution by adsorption onto acid activated red mud. J. Hazard. Mater. 2006, 138, 409-415. [CrossRef]

88. Ismail, A.A.; Bahnemann, D.W. Mesoporous titania photocatalysts: Preparation, characterization and reaction mechanisms. J. Mater. Chem. 2011, 21, 11686-11707. [CrossRef]

89. Liu, H.; Han, K.; Niu, S.; Lu, C.; Liu, M.; Li, H. Experimental Study and Mechanism Analysis of Modified Limestone by Red Mud for Improving Desulfurization. Int. Symp. Coal Combust. 2013, 465-477. [CrossRef]

90. Zhou, M.; Ji, Y.S.; Chang, Z.; Zhang, C.; Yan, X.T. Experimental study of alkali-activated red mud cement material. Appl. Mech. Mater. 2013, 357-360, 705-709. [CrossRef]

91. Ghosh, S.; Paul, A.K. Bioleaching of nickel by Aspergillus humicola SKP102 isolated from indian lateritic overburden. J. Sustain. Min. 2016, 15, 108-114. [CrossRef]

92. Sushil, S.; Alabdulrahman, A.M.; Balakrishnan, M.; Batra, V.S.; Blackley, R.A.; Clapp, J.; Hargreaves, J.S.J.; Monaghan, A.; Pulford, I.D.; Rico, J.L.; et al. Carbon deposition and phase transformations in red mud on exposure to methane. J. Hazard. Mater. 2010, 180, 409-418. [CrossRef]

93. Leal, P.V.B.; Magriotis, Z.M.; Sales, P.F.; Papini, R.M.; Viana, P.R.d.M. Effect of the acid treatment conditions of kaolinite on etheramine adsorption: A comparative analysis using chemometric tools. J. Environ. Manag. 2017, 197, 393. [CrossRef] [PubMed]

94. Qu, Y.; Lian, B.; Mo, B.; Liu, C. Bioleaching of heavy metals from red mud using aspergillus niger. Hydrometallurgy 2013, 136, 71-77. [CrossRef]

95. Buda, A.R.; Koopmans, G.F.; Bryant, R.B.; Chardon, W.J. Emerging technologies for removing nonpoint phosphorus from surface water and groundwater: Introduction. J. Environ. Qual. 2012, 41, 621-627. [CrossRef]

96. Bryant, R.B.; Buda, A.R.; Kleinman, P.J.; Church, C.D.; Saporito, L.S.; Folmar, G.J.; Bose, S.; Allen, A.L. Using flue gas desulfurization gypsum to remove dissolved phosphorus from agricultural drainage waters. J. Environ. Qual. 2012, 41, 664-671. [CrossRef] [PubMed]

97. Fois, E.; Antonio Lallai, A.; Mura, G. Sulfur dioxide absorption in a bubbling reactor with suspensions of bayer red mud. Ind. Eng. Chem. Res. 2006, 46, 6770-6776. [CrossRef]

98. Lu, J.; Liu, D.; Hao, J.; Zhang, G.; Lu, B. Phosphate removal from aqueous solutions by a nano-structured Fe-Ti bimetal oxide sorbent. Chem. Eng. Res. Des. 2015, 93, 652-661. [CrossRef]

99. Alharthi, A.I.; Hargreaves, J.S.J.; Pulford, I.D.; Gupta, N.; Balakrishnan, M.; Batra, V.S.; Singh, R.K. Hydrocarbon cracking over red mud and modified red mud samples. J. Sustain. Metall. 2016, 2, 387-393. [CrossRef]

100. Wang, X.; Zhang, Y.; Lu, R.; Zhou, F.; An, Q.; Meng, Z.; Fei, B.; Lv, F. Novel multiple coagulant from bayer red mud for oily sewage treatment. Desalin. Water Treat. 2015, 54, 690-698. [CrossRef]

101. Babuponnusami, A.; Muthukumar, K. A review on fenton and improvements to the fenton process for wastewater treatment. J. Environ. Chem. Eng. 2014, 2, 557-572. [CrossRef]

102. Chaerun, S.K.; Sulistyo, R.S.; Minwal, W.P.; Mubarok, M.Z. Indirect bioleaching of low-grade nickel limonite and saprolite ores using fungal metabolic organic acids generated by aspergillus niger. Hydrometallurgy 2017, 174, 29-37. [CrossRef]

103. Xu, H.; Cheng, W.; Jin, X.; Wang, G.; Lu, H.; Wang, H.; Chen, D.; Fan, B.; Hou, T.; Zhang, R. Effect of the particle size of quartz powder on the synthesis and $\mathrm{CO}_{2}$ absorption properties of $\mathrm{Li}_{4} \mathrm{SiO}_{4}$ at high temperature. Ind. Eng. Chem. Res. 2013, 52, 1886-1891. [CrossRef] 
104. Nereson, N.A.; Raymond, C.F.; Jacobel, R.W.; Waddington, E.D. The accumulation pattern across siple dome, west antarctica, inferred from radar-detected internal layers. J. Glaciol. 2017, 46, 75-87. [CrossRef]

105. Hamdi, N.; Srasra, E. Acid-base properties of organosmectite in aqueous suspension. Appl. Clay Sci. 2014, 99, 1-6. [CrossRef]

106. Fontes, V.J.B.; Simões, S.D.M.; Fernandes, T.D.S.; Varjão, A.E.L.; Santos, S.L.D.O.; Franco, J.M.; Santos, M.A.D. Pulmonary function and symptoms in asthmatics adolescents. World Allergy Organ. J. 2015, 8 (Suppl. 1), A266. [CrossRef]

107. Huang, Y.Z.; Hao, X.W. Effect of red mud addition on the fractionation and bio-accessibility of $\mathrm{Pb}, \mathrm{Zn}$ and as in combined contaminated soil. Chem. Ecol. 2012, 28, 37-48. [CrossRef]

108. Huang, Y.; Hao, X. The influence of red mud, bone char and lime on uptake and accumulation of $\mathrm{Pb}, \mathrm{Zn}$ and as by maize (zea mays) planted in contaminated soil. In Proceedings of the Third International Conference on Digital Manufacturing \& Automation, Guilin, China, 31 July-2 August 2012; pp. 922-926.

109. Zhou, R.; Wei, J.; Luo, L.; Zhang, J.; Zhou, Y.; Wang, Y. Effects of red mud addition on fractions of Cd, Pb and wheat root growth in calcareous soil. Chin. J. Environ. Eng. 2017, 11, 2560-2567. (In Chinese)

110. Eid, E.M.; El-Bebany, A.F.; Alrumman, S.A.; Hesham, A.E.-L.; Taher, M.A.; Fawy, K.F. Effects of different sewage sludge applications on heavy metal accumulation, growth and yield of spinach (Spinacia oleracea L.). Int. J. Phytoremediat. 2017, 19, 340-347. [CrossRef]

111. Li, B.; Yang, J.; Wei, D.; Chen, S.; Li, J.; Ma, Y. Field evidence of cadmium phytoavailability decreased effectively by rape straw and/or red mud with zinc sulphate in a Cd-contaminated calcareous soil. PLOS ONE 2014, 9, e109967. [CrossRef]

(C) 2019 by the authors. Licensee MDPI, Basel, Switzerland. This article is an open access article distributed under the terms and conditions of the Creative Commons Attribution (CC BY) license (http://creativecommons.org/licenses/by/4.0/). 